\title{
STERNGLASS: A CASE HISTORY
}

\author{
Andrew P. Hull \\ Health Physics \& Safety Division \\ Brookhaven National Laboratory \\ Upton, New York 11973
}

Ferdinand J. Shore

Queens College, City University of New York Flushing, New York 11367

\author{
Presented at the \\ Atomic Industrial Forum \\ Conference on Nuclear Public Information \\ Century Plaze Hotel, Los Angeles, California \\ March 5-8, 1972
}

\section{NQIIGE}

This report was prepared as an account of work sponsored by the United States Government. Neither the United States nor the United States. Atomic Energy Corsalssion, nor any of their employees, nor any of their contractors, subcontractors, or their employees, makes any warranty, express or implied, or assumes any legal liability or responstbility for the accuracy, completenegs or usefulness of any information, epparatus, product or process dis-" closed, or represents that its use, would not infringe privately owned rights.

\section{NoTICE}

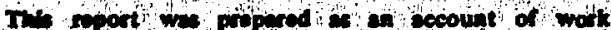

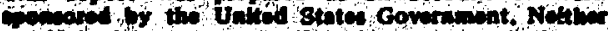

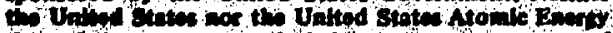

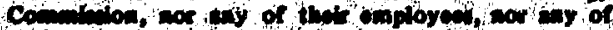

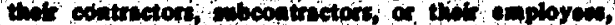

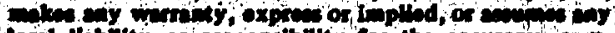

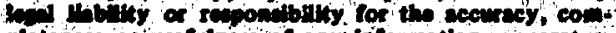

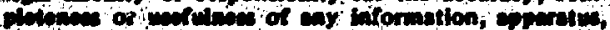

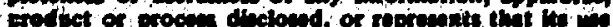

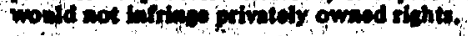

\section{i)}

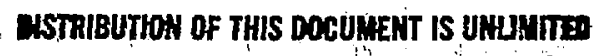

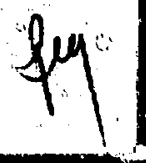


STERNGLASS: A CASE HISTORY*

Andrew P. Hul1

Health Physics \& Safety Division

Brookhaven National Laboratory

Upton, New York 11973

Ferdinand J. Shore

Queens College, City Univeraity of New York

Flushing, New York 11367

\section{ABSTRACT}

In recent years $\mathrm{Dr}$. Ernest Sternglass has repentedly questioned the AEC's IImits for the radiation exposure of the public from the effluent: of nuclear facilities. In several reports he has related the incidence of excess infant mortality adjacent to a number of these facilities, including nuclear power reactors, a fuel reprocessing facllity, nuclenr resenrch and development laboratories, and college educational and testing reactors. On this basis he has called for the lowering of atandards, moratoriun on the construction and operation of power reactors, and for exteasive epiderological studies to search for low-level radiation effects sternglass current arguments are an extension of those he has previously ande with regard to fallout and infant wortally.

A review of most of sternglese' fallout-related presentations and of the accompanying comentary discloses mich sclentlfie disagreanent wich his

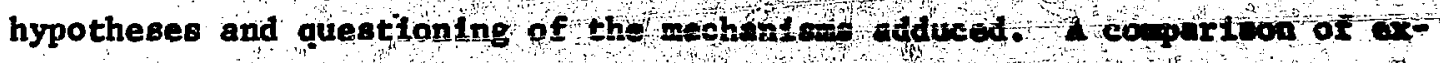

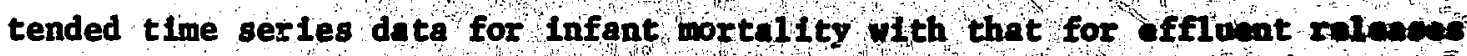
from five principal factilttes 1 plicated by stornglad, indicates the his correlations are Inotances of year to year atafical fluctuntion bout long term trends that do not support his arguments.

On the babls of establi hed dowe-effect ralationghipe, the averas pophlation dodes produced by auclear faclitts dffluphts are found to be arlare

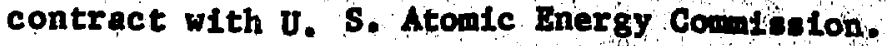


of magnitude too small to pxoduce the claimed mortality. The explanatory mechanisms adduced by Sternglass are not confirmed by experimental research, and depend on intakes of radioactivity into the body which cannot be demon8trated. Infant mortality appears to be 80 strongly correlated with other variables such as socio-economic circumstances, as to obscure the possibility of making meaningful studles of low-level radiation effects of nuclear facilfty produced exposures. 


\section{INTRODUCTION}

The first civilian nuclear power resctor in the United states, the Shippingport Atomic Power Station, became operational in 1957. During the next decade some fifteen additional 1ight-water-cooled power reactors went on-1ine at sites across the United States, with minimal public apprehension related to the risks occasioned by their routine radioactive effluents.

In the late $1960^{\prime} \mathrm{s}$ a growing public soncern for the quality of the environment became manifest. Concurrently, unchallenged application. for the construction and operation of power renctors became the exception rather than the rule. The initiatives for these challenges were for the wost part made by local environmentalist and conservation groups. However, they have called upoi a sma1l cadre of nuclear critics from the scientific comity for expert support of their arguments, both in public hearsinge and in formi licensing proceedings.

Dr. Ernest J. Sternglass, a radiation physic ist at the Dniversity of Pittsburgh, has been among the foremost of these critics. In an extenoton of his previous much publicized argumente with respect to fallout, he has more recently turned his attention to infint mortality in the vicinity of nuclear facilitieg in general, with particular enphate on nuclear powax reactor 8.

On one or more recent public appearances as a sclontiflc expert, Sternglass has presented the findinge of reports $(1-12)$ in which he bas related the incidence of excess Infint wortalify to the poutine redionetive

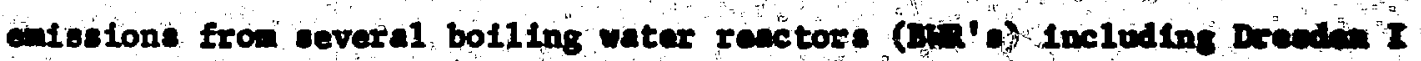

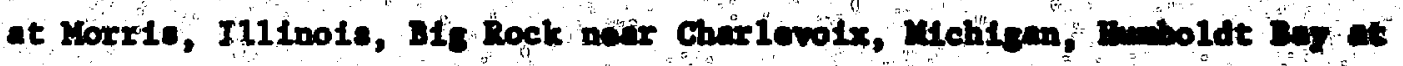

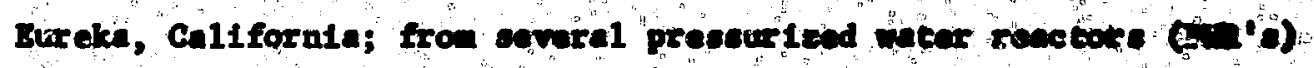

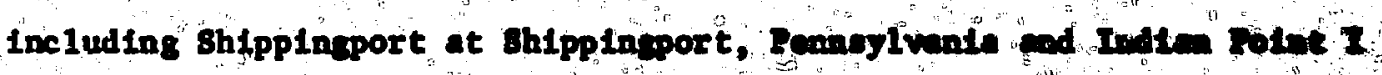

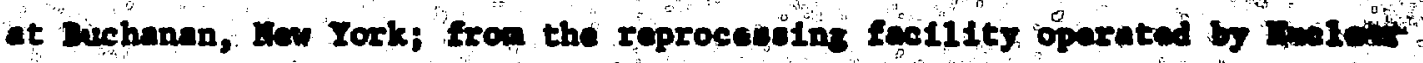

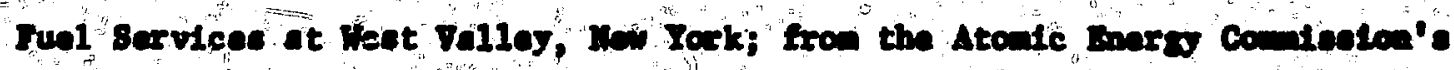


nuclear research and development facilities including the Hanford Atomic Production Works at Richland, Washington and Brookhaven National Laboratory at Upton, New York; and from the omall educational and testing reactors at the Pennsylvania State University in State College, Pennsylvania, and at the University of Il1inois in Urbana, I11Inois, and at the Gulf General Atomic Corp. research laboratory in San Diego, California.

In common with most of the other more outspoken nuclear critics, Sternglass has not utilized first-hand research to buttress his claim that the effects of low-level radiation have been underevaluated in the U. S. Atomic Energy Conmission's protection standards (13) of 500 milliroentgens per year to individuals adjacent to nuclear facilities and 170 milliroentgens per year average to large populations. These essentially follow the recommendations of the International Commission on Radiological Protection (14) and the National Comittee on Radiacion Protection and Measurements (15). His principal evidence consiets of his interpretations of yearly infant mortality data, as reported in the U. S. Vital statistics and by Individual state health departments.

In several studies he has made time serles correlations of Infant nortality with nuclear facllity affluent releases, and has thus hypothesized a relationship between them. Dx. Steinglass has not defined a precise.doseeffect relationohip, nor hes he indicated a mechanisn to account for the extreme sensitivity of the infant in utero which his observations inply. Rather, in his current studies he has essentialig repeated suggestions ande earlier in his similar studies of fallout and Infant mortallty, that unsuspected high concentrations of effluest radionuclides my occur in certain glands of the body that are critical to reproduction and development, such as the gonads and the pituitary. 
As was the case with his follout and infant mortality claims, many aspects of Sternglass' current reactor-related studies have been strongly disputed. For the most part this argument has taken place in public hearIngs and proceedings. Little if any of it has appeared in scientific channels, where it could be widely subject to the peer group evaluntion customarily used to establish the validity of a controversial scientific hypothesis.

Although it has recelved 11ttle sclentiflc review, Sternglass' argunents, along with those of his fellow critics, appear to have been effective in creating a climate of public concern about radiation protection standards, farticularly in the context of their application to nuclear power reactors. The AEC has recentiy proposed ${ }^{(16)}$ a reduction in these 1 imits, specificaliy for exposures of the public from 11ght-water-cooled power reactor effluents, to $1 \%$ of the above amounts. Although denied by the Comiasion, in the ninds of many persons ${ }^{(17)}$ this proposal appears to be a reaponse to critic-generated pressures.

On varlous occestons Sternglass has called for abstantial lowering of radiation protection standards, for the discontinunnce of the operation of all BWR'B, for a moratorium on the construction of additional reactors and other nuclear facilities, and for the extanaton of the Ac's proposed 11wits for 11ght-water-cooled powar reactore to ali other muclear factlittas onig has been coupled with a call for far nore extengive epiderological btudies than his, to be conducted by Independent ecientist (not connected alth agencles responstble for otandarde setting or enforcanent) to cearch for low-level radiation effects. In a recent popular agase article (18) Sternglase was portrayed as a "controversial gelontiat, wagling a atubborn

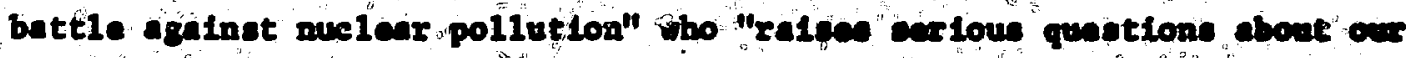

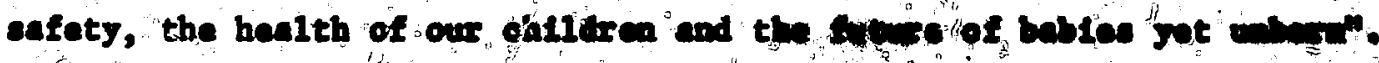


this article, the authors were critical of the "AEC's reluctance to Investigate Dr. Sternglas8' findings".

The foregoing leads to several related queations:

1. Do the data oupport Sternglasg' call (and the AEC'B current proposals) for lowering radiation exposure 1 imits?

2. Do they oubstantiate calls for emergency actions, ouch as a shutdown of existing power reactors and for a moratorium on power reactor conetruction?

3. Do they constitute a resconable basis for making more extengive epidemological studies to search for low-level radiation effects?

In what follows, from an extimination weing the Sternglase methodology of vital statistics and effluent release data fxom several of the facilities adjacent to which he has found excess mortality, from an examination of the related effluent doses and of the indicated incidence of infant mortality in the light of established dose-effect relationohips, and by a consideration of other factor which have been correlated with infant mortality, anowers in the negative are suggeated.

Sternglass has relied heavily on his previous output denling with infant mortality and low-1evel radiation to upport his recent presentations: A review of it therefore seems essential to en overall understanding of his current position.

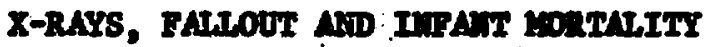

Sternglase has for aome time beeib particuiarly concerned about the sensitivity of the foetur to Irradiation in utero. As far back as 1963, he argued (19) that experimental evidonce previouoly oet forth by stenart and Mackahon on the effecte of preantal diagnostic $x$-ray exposure indicated a Iincar reoponce and the absence of a threshold for the developant of childhood cancer and leukenia, for total dosed well below one roentgen. At that tine he also ouggented that this senoltivity abould mas it posaibla to observe 
the effects of comparable exposure in utero to normal background and to fallout. It should be noted that Sternglass was shortly thereafter crit:cized by several scientists including Mackiahon $(20-22)$ for making numerous arbitrary assumptions to support his argument, as well as for ignoring other studies using other methods for selecting controls.

Al though Sternglass does not appear to have followed up his earlier ouggestion with any studies of background radiation level effects; he subsequently made a number of presentations $(23-30)$ in which he associated radioactive fallout with childhood leukemia and/or infant mortality. In these presentations he depicted increases in successive yearly nortality rates as being fallout-related, considering years prior to and years in which or after which atmospheric nuclear weapons tests were conducted. However, his principal evidence for this relationship was based on the occurrence of a less steep decline in infant mortality after the advent of large scale weapons testo around 1950, than the decline during the period from 1935-1950. By comparing the post 1950 data with a projection of the 1935-1950 rate, he arrived at numbers of "excess" infant deaths, which were graphically correlated in tine with current or previous years in which wenpons tests had been conducted. As a causal 11nk, Sternglass postulated an extra effect of fallout, in addition to the external radiation effects of in utero exposure of the foetus from its and/or its mother's internal body burden of short-i ived fallout nuclides. He cited a 1963 study by Iuning in support of a hypothesie that ${ }^{90}$ Sr and its daughter ${ }^{90} \mathrm{~T}$ posed an unsuspected potential for "genetfe" damage to the newly developing foetus.

Ae Indicated by Graham and Thro ${ }^{(31)}$ and Boffey ${ }^{(32)}$, in their raviewe of this phase of Sternglase' activities, this developant of his ancliex arguments were extenstvely and vigorously challenged by other scientiste $(33-42)$ He was charged with anking arbitrary assupptions; porticularly in his cholce 
of baselines and of comparison years. His use of epidemological statistics and his neglect of other probable causes for Infant mortality were also questioned. In addition, Luning is reported by the above reviewers to have repudiated the pertinence of his Investigations to Sternglass' hypothesis.

As was indicated by some of his critics at that time, Sternglass had on some occasions suggested that the relationship between his infant mortality and fallout levels was an immediate one, and on other occasions that it had about a five-year lag. The excess infant mortality for the United States during the $1950^{\prime} \mathrm{s}$ and $1960^{\prime} \mathrm{s}$, as arrived at by Sternglass, is shown in Figure 1. For comparison purposes, the pattern of the cumulative fallout In the United States, as suggested by externe1 background measurements previoubly reported ${ }^{(43)}$ for Brookhaven National Laboratory on Long Island, has been added. Whichever is postulated, an immediate or five-year lag, the fit between the patterns of excess mortality and background seems less satisfactory for the post 1960 data, than for the carlier period for which Sternglass first propounded a relationshtp.

Since it represented an Independent counterpart approach, rather than a critique of Sternglass' fallout and infant mortality studies, Shav and Silth's study ${ }^{(44)}$ of ${ }^{90} \mathrm{Sr}$ and infant mortality in Canada has perhaps cast the greatest doubt on his fallout findings. In this study they found that, although ${ }^{90} \mathrm{Sr}$ levels there were somewhet higher than in the United States, no association was apparent between them and provinclal or overall Canadian Infant mortality.

A review of the 1iterature relative to the controversy over fallout and Infant mortality discloses no authoritative scientific support at that time for Sternglass' case beyond statements $(31,32)$ to the effect that the possible connection between fallout and Infant nortalty should be fully invertigated. More recent $1 y^{(12)}$ starnglase has Indicated that on unpibilishod epldenological 
study by Lave et al. (45) has also found infant mortality to be "strongly associated with strontium-90 levels in milk". A1though these studies do suggest a positive correlation, it does not appear sufficient to explain the "excess" Infant mortality Sternglass has postulated. In addition, the author's Indicate that their estimates may not be substantiated by additional analyses, aince the data employed were incomplete, inadequate and possibly inconsistent.

\section{NUCLEAR FACILITY EFFLUENTS AND INTANT MCRTALITY}

Most recently, Sternglass has shifted his attention to nuclear facilities and to an examination of, infant mortality rates in their vicinities: In a series of presentations $(2-4,6,11)$, he has made comparisons between infant mortality rates for pre-staztup or pre-peak releaze years with the rates for post-startup or peak release years, for more than a dozen nuclear facilities. These comparlsons have been made for counties or states in which the facllities were located, in relation to those of adjacent counties or states. He has found one or more instances of a correlation between infant wortalfty and the effluent releases associated with the routine operation of wost of the facilities he has considered.

It is important to an evaluation of Sternglass' allegat tons thet one understands the use of vital statisties data and the central assumptions that can be made about the statiatieal variation these data enhisit as titey are observed in a time serles A discussion of this topte can be found in the Vital Statistics of the United States (46) It ouggests ohat the numero of births or deschs represent complete counts of ouch events and as ach ar not subject to sampling error. However, when the flgures are upod for puch purposes as the comparison of rates over a time period or for diffangt areas, the number of events that atully occured may be conslder of a of of a large serles of possible results that could heve arisen und of the 
ctreostances. The probable range of values may then be estimated from th: setuel figures according to elementary statistical assumptions.

Fron these assumptions, it follows that when the number of events is andil they may be assuned to follow a Polsson probability distribution. Accordingly, the standard error of an observed number of live births, $B_{1}$, my be taken to be $\sqrt{B_{1} ;}$ of deaths, $D_{1}$, to be $\sqrt{D_{1}}$, etc. The standard error of mortality rate, $M_{1}=\frac{D_{1}}{B_{1}}$, may be taken to be $\sqrt{\frac{M_{1}}{B_{1}}}$, where by definition of Iafant wortality, $D_{1}$ includes those occurring between 0 and 1 year. The Vikel stetistics guidance is that the difference between the two rates may be regarded ag atatiatianily significant if it exceeds two standard errors, that is (2) $\sqrt{\frac{M_{2}}{D_{2}}+\frac{W_{2}}{D_{2}}}$.

Some eatimates of anticipated varlations in mortality rates and of the difference required to establish otatistical significance may be useful in evaluating what follows. To a firat approximation, the birth rate in the United Statee dusing the period under consideration was about 20 per 1,000 total population, and the 0-1 year infant mortality rate was about 20 per 1, eno 11ve births. Jaing these approximations, projections of the total yeurly births, the totsl infant mortality, the anticipated two standard deviation error for the assumad infant mortality rate (20/1,000 1ive births), and the required difference in rates to demonstrate statistically significant departure from the assumed mean have been calculated, for a number of census unite ranging in population from 2,500 to $1,000,000$. The results are shown In Tabie I. The indicated differences are assumed to be particularly applicable to asgesing of gntfleant differences in mortality rate from year to jent within given locale, In which the total population and total bixths chenge only olightly.

In the papar (9) which he presented before the Health Physics Society in 1971, Bteraglase ande the following statement: 


\section{TABLE I}

Estimated Difference In Infant Mortality Rates Required to Batablish Statiatical Significance

Total

Populatioi Total Population at $20 / 1,000$

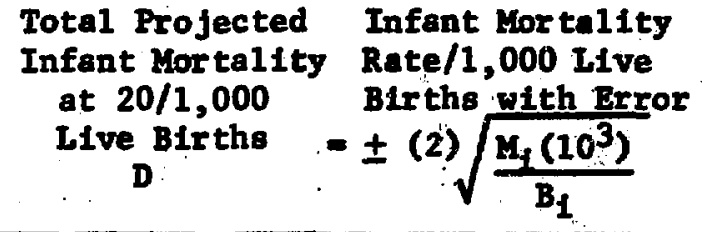
Total Projected Infant Mortality
at $20 / 1,000$
LIve BIr ths

Total Projected Yearly Births

B
Required Difference

In Rates for

Statistical sfoniflcance $=(2) \sqrt{\frac{M_{1}^{2}}{D_{1}}+\frac{H_{2}{ }^{2}}{D_{2}}}$

\begin{tabular}{|rrrrr|}
\hline 2,500 & 50 & 1 & $20 \pm 40$ & 57 \\
5,000 & 100 & 2 & $20 \pm 28$ & 40 \\
10,000 & 200 & 4 & $20 \pm 20$ & 28 \\
25,000 & 500 & 10 & $20 \pm 13$ & 18 \\
50,000 & 1,000 & 20 & $20 \pm 8.9$ & 13 \\
100,000 & 2,000 & 40 & $20 \pm 6.4$ & 8.9 \\
250,000 & 5,000 & 100 & $20 \pm 4.0$ & 5.7 \\
500,000 & 10,000 & 200 & $20 \pm 2.8$ & 4.0 \\
$1,000,000$ & 20,000 & 400 & $20 \pm 2.0$ & 2.8 \\
& & & & \\
& & & &
\end{tabular}

NOTE:

$$
\begin{aligned}
& \sigma_{M_{1}}=\sqrt{\left(\frac{M_{1}}{D D_{1}}\right)^{2}\left(\Delta D_{1}\right)^{2}+\left(\frac{B_{1}}{\delta B_{1}}\right)\left(\Delta B_{1}\right)^{2}}=\frac{D_{1}}{B_{1}} \sqrt{\frac{1}{D_{1}}+\frac{1}{B_{1}^{2}}}, \\
& \text { If } \quad B_{1} \gg D_{1}, \frac{D_{1}}{B_{1}} \sqrt{\frac{1}{D_{1}}+\frac{1}{B_{1}}} \approx \frac{D_{1}}{\frac{1}{B_{1}}}=\sqrt{\frac{M_{1}}{B_{1}}}
\end{aligned}
$$

and

$$
\begin{aligned}
\sigma\left(M_{1}-H_{2}\right) & =\sqrt{\left(\Delta M_{1}\right)^{2}+\left(\Delta M_{2}\right)^{2}} \approx \sqrt{\frac{M_{1}}{B_{1}}+\frac{H_{2}}{B_{2}}} \\
& =\sqrt{\frac{M_{1}^{2}}{D_{1}}+\frac{M_{2}^{2}}{D_{2}}}
\end{aligned}
$$


"A similar pattern of increased infant mortality has now been observed around three commercial nuclear power reactors of the bolling water reactor type ....."

and he went on to Identify Dresden I, Humboldt Bay and Big Rock Point as being responsible for excess infant mortality. This evaluation of Sternglass' claims will again discuss some of the data he presented in that paper. It is supplemented by the presentation of a more complete time series, in order to put it into perspective in terms of fluctuations and a more comprehensive statistical analysis.

With regard to the Dresden I reactor, located in Grundy County, Illinois, Sternglass showed for the counties adjacent to the reactor that, corresponding to an Increase in the yearly release of gaseous effluents, the infant mortality rate increased substantially in the year 1966, as compared to 1964. Included were control counties in northwestern Illinois. These data are shown in the left hand portion (1966/64) of Figure 2 (which corresponds to Sternglass' Figure 17). In Grundy the percentage Increase was 141\% for 1966 over 1964. Was this a significant matter? At the $95 \%$ confidence level, the percentage change was $141 \pm 216 \%$. The gaseous emissions from the reactor for the various years are also included. Examination of the figure indicates that for the years 1964 and 1966 (chosen by Sternglass) the gaseous anissions increased from 500 to 700 curies, an increase of $40 \%$.

Table II is based on Information offered by Sternglass as evidence that marked changes occurred in infant mortality for Grundy County and for some adjacent counties such as Livingston and Kankakee, whereas the 80-called control counties did not show such chnnges. In addition to the data shown originally, the births and deaths in the adjacent counties and in the control counties have been totaled. It can be seen that the asjacent counties increased by $(16.8 \pm 22) \%$ and controls by $(1.1 \pm 20.2) \%$. If this increase in Infant mortality is actually due to a $40 \%$ increase in radioactive gaseous 
TABLE II

Infant Mortality Chenges 1964-1966 Near Dresden, Illinols

County

Grundy

Livingston

Kankakee

พI11

LaSalle

Rendall

Adjacent Sum
Deaths $\frac{1964}{\text { Births Ratel1000 }}$

7

442

15.8

8.2

728

20.7

22.2

22.5

41

11

2,176

460

23.9

223

10,702

20.8

$854 \quad 18.7$

122

5,002

24.4

930

18.3

978

25.6

19.5

25.8

658

9,552

22.9

219

1,130
Deathe Births Rate/1000

18

474

38.0

12

608

19.7

$54 \quad 1,830$

29.5

23.3

$100 \quad 4,292$

39. 1,858

422

7

230

9,486

16.6

24.3

$(16.8 \pm 22) \%$

Control Sum

.

20

808

24.8

$+33$.

122

4,788

25.5

+5 .

16

862

18.6

$+2$.

20. 808

24.8

$-3$.

17

946

18.0

$-8$.

$9 \quad 594$

15.2

-41 .

204

8,806

23.15

$(1.1 \pm 20.2) \%$

Source: E. Sternglass Table I of Ref. 12; except addition of sums of number for adjacent and control counties and uncertainties in percentages indicated.

* If $M=\frac{D}{B}$, and $P=\frac{L_{2}-M_{2}}{H_{2}} 100, \Delta P=100 \frac{M_{D}}{L_{2}} \sqrt{\frac{1}{D_{2}}+\frac{1}{B_{2}}+\frac{1}{D_{2}}+\frac{1}{B_{2}}}$ 
emisaions, then it should be even larger for a larger percent increase in enfssions. But this expectation is contrary to fact. If, instead of 1964 , the year 1960 (In which essentially no emiseions occurred) or 1963 (In which only 90 kilocurles were emitted) are chosen for comparison with 1966, one finds that the adjacent counties decreased relative to then. In addition to the results for 1966 relative to 1964, Figure 2 show conparisons for 1966 relative to 1963 and 1960. It is apparent that the logic which gave Sternglass the "Iarge" 1966/1964 effect, ylelds Inconsiatent resulto when applied to $1966 / 1960$ or $1966 / 1963$. When coupared with the closest corresponding row of Table I, it 18 also apparent that none of the infant mortality rates shown departs significantly from the overall averages of sightly more than 20 per 1,000 11ve births.

The results of any analyols of a larger sayple of years, those from 1955 through 1967, for which Vital Statiotics records were avallable, are summarized in Table III and FIgure 3. To nininize the fluctuations because of small numbers, the mortality rates for the combined counties innediately surrounding the reactor were chosen, and similarly the rate for the sun of the 81x Sternglass control counties. It is apparent that 1964 was the year of emallest Infant mortality rate, of all the years 1955 to 1967 . Une of this year would therefore give the largest numerical change if one used ratios in the same manner as Sternglass has. However, it appears more consistent with the Increase in releases to compare 1966 with the years 1960 or 1963. One might aleo Inquire about a larger control area, both populationwise and geographically. The rural counties are prinarily white. It therefore seems appropriate to use the white population of Illinois, since its Infant mortality rate is only half that of the non-white population. Local trends due to geographical peculiarities within the state would presumbly be averaged out by taking sts entire white population as a control. 
TABLE III

Dreaden I Infant Mortality Comparisons *

Infant Death Rate

Year

\section{Ad jacent Control}

Count ie tht 1 diecent Counties
Infant Death Rate

Illinole Illinole Illinols Adiacent Countins

Total White Won-White IIIInols White

\begin{tabular}{|c|c|c|c|c|c|c|c|}
\hline 1955 & 27.1 & 22.8 & 1.190 & 24.8 & 22.0 & 42.1 & 1.23 \\
\hline 1956 & 27.2 & 23.4 & 1.162 & 24.5 & 21.8 & 40.8 & 1.25 \\
\hline 1957 & $24.8 \pm 3.0$ & $24.3 \pm 3.0$ & 1.019 & 25.5 & 22.2 & 44.0 & 1.111 \\
\hline 1958 & 24.3 & 24.2 & 1.004 & 24.9 & $22.4 \pm 0.68$ & 38.7 & 1.085 \\
\hline 1959 & 23.5 & 26.9 & 0.874 & 25.0 & 22.4 & 38.6 & 1.050 \\
\hline 1960 & 26.0 & 25.6 & 1.014 & 25.0 & 22.2 & 39.6 & 1.17 \\
\hline 1961 & 24.4 & 22.4 & 1.089 & 24.3 & 21.8 & 37.2 & 1.12 \\
\hline 1962 & 21.1 & 22.6 & 0.934 & 24.0 & 21.2 & 37.6 & 0.995 \\
\hline 1963 & 24.0 & 23.1 & 1.039 & 23.9 & 20.9 & 38.7 & 1.15 \\
\hline 1964 & $20.8 \pm 2.6$ & $22.9 \pm 3.2$ & 0.908 & 25.1 & 21.4 & 43.5 & 0.97 \\
\hline 1965 & $26.4 \pm 3.2$ & 21.5 & 1.228 & 25.6 & $21.4 \pm 0.70$ & 44.5 & 1.23 \\
\hline 1966 & $24.3 \pm 3.2$ & 23.2 & 1.045 & 25.2 & 21.2 & 41.9 & 1.15 \\
\hline 1967 & 21.6 & 23.4 & 0.925 & 23.6 & 20.4 & 36.9 & 1.06 \\
\hline $1968^{\dagger}$ & 23.0 & 19.4 & 1.185 & - & H.A. & & - \\
\hline $1969 t$ & 21.4 & 23.3 & 0.920 & - & 19.1 & & 0.92 \\
\hline $1970^{t}$ & 24.6 & 19.6 & 1,254 & - & 18.5 & & 1.25 \\
\hline
\end{tabular}

* Bote: In 1969 for Grundy and IIvingeton counties, Infant deathe consisted of 99.87 white children. The 6 adjecent counties had 92.47 white deaths and the controls had 92.9\% white deaths. Illinols had $80.2 \%$ white deaths. Source: Vital statistics of Illinola, 1969.

tt Adjacent Counties: Grundy, Livingeton, Rarkakee, W111, LaSalle and Kandal1

tht -Sternglase Control Counties: Ogle, WInnebago, Henry, Stephencon, Inox and Lee

+ Data E. 1968, 1969 and 1970 fron Vital Statistics, Illino1s, 1969, and aupplementa1 Information provided by C. Bridger, Dept. of Public Health, State of Illinois: 
In eny event, when divided by the I11inols white population rate, the edjacent county death rate does not show any increase after plant startup. Rather the rate decreasen for both cases, when compared with either the rate for Sternglass control counties or for the white population of the state.

Continuing to other nuclear power stations in this sare presentation, Sternglass stated:

"Identical patterns of riees in infant mortality have now been found for two other boiling water reactors, as shown in Figure 19 for the group of amn11 counties around the Big Rock Point Plant in Michigan, and in Figure 20 for the Humboldt reactor near Eureka in Eumboldt County, Horthern California. Again there is a sharp halt in the normal decline of infant mortality following release of large quantities of gaseous activity comparable to those released at the Dresden Reactor, while more distant areas continue their decline, shown for the Humboldt area in Pigure 21."

At the top of Bigure 4, the infant mortality rate for the ten nearest counties to the Big Rock Point Reactor for the years 1955-1967 is shwin. The 95\% 11mits of confidence are chown, and in addition the rate for the white population of the state of Michigan is given. At the botton the gaseous enissions for the same years are shown. It is evident that for the years prior to startup, the infant mortality rate in the adjacent counties tended to be approximntely one standard deviation higher than for the white population in the state. But after reactor otartup one finds that the adjacent county death rate approximated that of the atate. The middle section of Figure 4 depicts the ratio of the mortality rates for the adjacent countiea divided by the statewide white infant wortality rate. It appears that instead of a sharp halt in the normal decline in the rate for the nearby countiea, as atated by Sternglass, if anything there was in fact an accelerated decline after reactor startup. For example, for the three years 1960, 1961 and 1962, just prior to reactor eniasions, the ratio 1s $1.25 \pm .12$, whereas by comparison, for the years 1965,1966 and 1967 , 
straddling the years of greatest gaseous emissions, the ratio is $1.01 \pm .16$. These data are oumarized In Table IV.

In the center of Figure 5, the percent change in infant moztality rates for countles near the Humboldt Bay Reactor In the years 1965 over 1964 Is shown. It is similar to Figure 8 in Sternglass' presentation. From it one obtains the impression that infant mortality increased near the reactor, whereas for wore distant counties it decreased. Taking the year 1964, in which emissions were almost zero, as the normalizing year, and conparing it as Sternglass has with 1965 in which the emissions were approxinately 300 kllocurles, seems reasonable enough. But what happens when one compares the mortality lates for other years with those for 1964 ? Figure 5 also shows the result of doing this. In 1967, when emissions were three times larger than in 1965, the three nearest counties had even gmalier death rates than before the reactor started afgnificant emissions. Hote that with no enissions, 1963 relative to 1964 gives somewhat similar results to the years chosen by Sternglass. The changes appear to be the typical statistical fluctuations in vital rates.

The infant mortality rate for the year. 1958-1969 are shown in Figure 6. Included are the rates for Humboldt County, in which the reactor is locatad, the aggregate mortality rates for the nine nearby counties chosen by Sternglan, and the rates for the white children in the state. The 1961 point for Humboldt County also shows the two standard deviation range. These data are summarized In Table $V$.

The years 1964 and 1965 chosen by Sternglase for comparison were the years in which the largest change in infant mortality occurred in funboldt County. The number of deathe in this county is ana11, typically about 50 deaths per year. By reference to Table I, a conndderable scatter in the Humboldt County points would be anticipated. Howevar, after 1964 the 
Infant Kortality Rates/1000 for Counties Hear $3 i g$ Rock Point, Michigant

\begin{tabular}{|c|c|c|c|c|}
\hline Year & $\begin{array}{l}\text { Ten County } \\
\text { Rate }\end{array}$ & $\begin{array}{l}\text { Kichigan } \\
\text { White }\end{array}$ & & $\frac{\text { Ten County Rate }}{\text { Hichigan White Rate }}$ \\
\hline 1955 & 24.2 & 23.2 & & 1.04 \\
\hline 1956 & 26.1 & 22.9 & - & 1.14 \\
\hline 1957 & $28.9 \pm 6.4$ & 23.0 & & $1.26 \pm 0.32$ \\
\hline 1958 & 25.8 & 23.3 & & 1.11 \\
\hline 1959 & 24.4 & 23.0 & & 1.06 \\
\hline 1960 & 26.0 & 22.1 & & 1.18 \\
\hline 1961 & 30.1 & 22.6 & & 1.33 \\
\hline 1962 & 27.6 & 22.4 & & 1.23 \\
\hline 1963 & 25.1 & 21.5 & & 1.17 \\
\hline 1964 & 23.5 & 21.0 & & 1.12 \\
\hline 1965 & $19.9 \pm 5.8$ & $21.6 \pm 0.8$ & & $0.92 \pm 0.28$ \\
\hline 1966 & 20.1 & 20.0 & $\cdot$ & 1.00 \\
\hline 1967 & 22.2 & 19.8 & & 1.12 \\
\hline
\end{tabular}

*osed data from U.S. Vital Statistics 
Humboldt County rate appears sma11er and closer on the average to the death rate for the state, than it was before reactor emiselons conenced. For the nine nearby counties it is evident that the rate is statiatically close to that for the white children in the state. However, prior to 1963 the adjacent courty rate tended to be ofgnificantly above the white state-wide rate. These qualitative atatementa for the nearby counties are better indicated by the plot in the widdle of Figure 6 , which gives the ratio of the adjacent counties Infant death rate to that of the state's white population. It is evident that this ratio was leos from 1965 onvard than from 1958 to 1964. This observation is opponite to the Inpression given by the Sternglass data.

Other allegations about Infant wortelity in metropolitan Hew York and environe due to the operation of Indian Point I and the Brookhaven Graphite Research Resctor (BGRR) were precented ${ }^{(8)}$ by Sternglass at the Shorehan Atomic Safety and Ilcensing Board (ASLB) henrings. A considerable listing of tables of lata for the years $1958-1969$ of infant wortality in many Nex York State counties and also a table, which gave the radioactive waste discharges from Indian Point Unit No. 1 for the yeare 1963-1969 were Included. Several graphs based on the tabulated data were included, and mantion was maje of statistical fluctuntions, correlation coefficients and levels of significance. As a means of cancelling out wocto-econonic differences between the reactor environs in the Westchester-Bockland area and thet in any distant control county, Sterngless indieated:

\footnotetext{
"Thus, Weotchenter and Rockland an' be compared nost closely with Iasenu County, Ions Island, eince it has a aimilar totel population of cloce to one nillion ofiniar ouburban character, and closely sinilar fallout levels, as well as sinilar socio-econonic chrracteristice."
}

In Figure 7 the calculated ratio of Infant wortality rates in wistchentar plus Rockland to that in Basexu for the yeare 1969 is shows. The least equares 
fitted straight line has a negative slope, ouggesting that the ratio of Infant wortality near the Indian Point Reactor, when coupared to Hassau, was larger in 1955 than in 1969. The yearly gaseous eafisions are also indicated. It may be noted that these are miniscule compared to the previous cases. Sternglass selected 1966 and compared it with 1961 . When many yearo data are examined, it appear that the year 1965 had the anallest mortality ratio of any before otartup, while 1966 had the largest nortality rario. The fluctuacions for all fifteen years fall within two standard deviations of the trend, and there is an inverse correlation between gaseous enisolons and infant mortality near the reactor. Sternglass asserted in his testimony and showed graphically that if one chose the years 1961 and 1966 for comprison, and calculated the percentige change in 1 ifant wortallty for selected counties, that the wortality changes decreased with a "one divided by distance" $\left(\frac{1}{D}\right)$ behavior. If redioactive gaseous emisalons were causative this aght be a reaconable first assunption, and on its face, it could be persuasive. The percentage change of the infant nortality of 1966 over 1961 in the various county groups selected by Sternglass, and which are at various distances to the north and south of Indian Point $I$, are shown in Figure 8. The changes can be seen to be greatest near the reactor and decrease with distance, as aserted by sternglass. Pursuing this logic further, since In 1968 compared to 1962 the increase in gaseous reactor enisstons was even greater ( 59.7 curles) than for 1966 compared to 1961 (36.4 curles), greater mgnitude changes (167h) would be expected, but the $1 / \mathrm{D}$ dependence should be the sane. The renulte, as also shown in Pigure 8, are otherwise, suggesting that any pattern in these chenged is an axtifact of the anmual variation in mortality rates.

The dangers in drawing inferences from selected cosparisons in vital rate time ceries vere vell illustrated when in this sane presentation 
Sternglase associated "the anomalous rise of Infant wortality In suffoly between 1953 and $1960 \ldots$ with the reported activity produced at Brook haven and the fraction released into the otreams". The annual infont mortality rates for Suffolk County from 1949 to 1969 are ohow in FIgite 9 (the BGRR operated from 1951-1968). Also shown are oimllar data for neighboring Nassau County on Long Island, and for New York State, minus New York City. It is difficult to ascertain what is "anomalous" about the Suffolk data. The curves appear consistent with the anticipated annuai fluctuations and with the expectation that as the population unit increases these fiuctuations decrease. In 1950, Suffolk County was atill largely rural, with a population of 276,129. By 1960 this had Increased to 666,742 , and by 1970 to $1,127,030$. For the corresponding years the Nassau County populations were $672,765,1,300,171$, and $1,428,838$, while the New York State populations (except New York CIty) were $6,938,235,9,000,320$, and $9,346,703$.

The yeariy amounts of BLI 1iquid effluent activity, which Sternglass associated with the increases in infant mortality between 1953 and 1960 , are \&180 shown in Figure 9. The Peconic River flows easterly through very sparsely settled territory. Most of Suffolk's populatioh was and 18 located to the west of the Peconic water shed. In addition, this stream is nowhere used for drinking or Irrigation. The maximum possible exposure attributable to Brookhaven effluents in It was a few millirem/year to the consumers of fish obtained by a few sports anglers in the comparatively unproductive upper reaches of the stream. The average dose to infants in suffolit County from this source was essentially zero.

Sternglass appears to have Incorrectly assumed that the gaseous and IIquid effluents at BXL were in correspondence. The overage yearly exposure rates at the BLL perimeter, primarily from the BGR effluent 41 , are also shown In Figure 9, as are the external backgrounds, including the increments 
fros fallout as measured at the same location. A comparion of the latter with the infant mortality in Suffolk County shows; if anything, an Imvaree correlation. Infant mortality in Suffolk declined during the early 1960' when the BrL effluent and fallout doses were at their maximum rates.

In the precedir diserssions, methods corresponding in principle to Ehowe wtillad by stermglase for investigating infant mortality and the tifluent refenses have been employed. When the data are analyzed in the context of an extended time serles, most of the comparisons cited by Sturatias seba readily explainable as normal statistical fluctuations in intant morteli rateo,

In weward anfev there ire logical reasons for belecting other portions

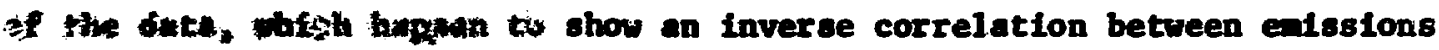
and infant wortality. On the reaconing that Sternglase has enployed, this 4xif Hat to the conclusion that low-level radlation decreased infant norcal15y. It sams doubtful that any scientiet propounding this notion on auch Iinted orldence would have been seriougly listened to by either his pacts or by the pubitc.

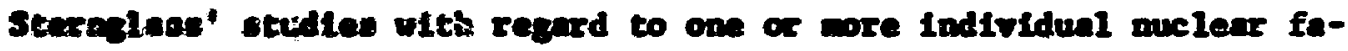

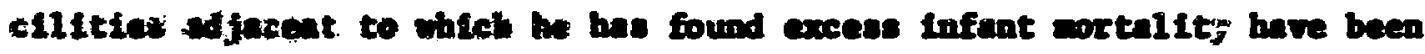

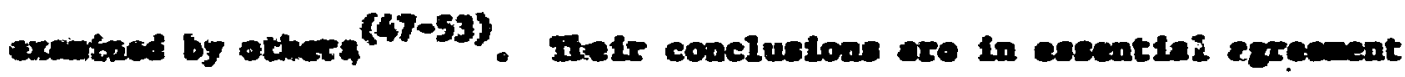

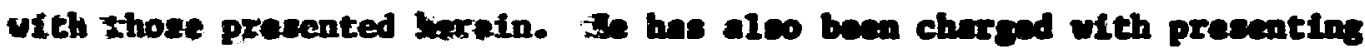

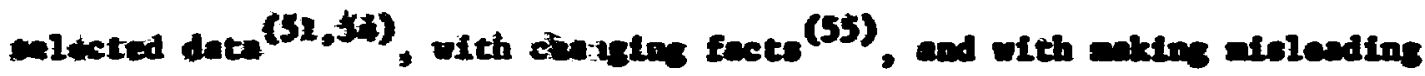

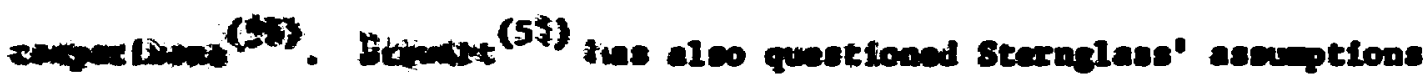

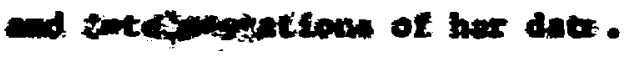

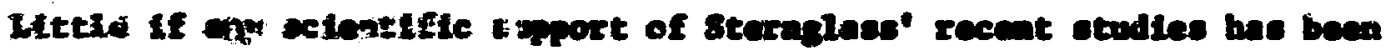

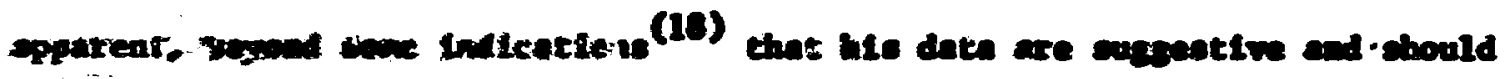

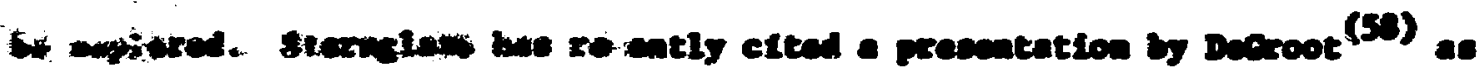


a separate detection of Infant mortality in the vicinity of Dreaden $I$, Indian PoInt I and Brookhaven, even though the latter summarized them as preliminary and inconclusive.

\section{DOSE}

If the Sternglass claim that he has detected a relationship between Infant mortality and nuclear facility effluents appears to be questionable on statistical grounds, it seems even more so from dose "signal to nolse" ratio considerations. He has claimed $(7)$ the "extra risk" of infant mortality at the presently permitted maximum exposure rate $(500 \mathrm{mR} / \mathrm{yr})$ is 61,880 deaths per million children born. If this $18 \mathrm{so,}$, then the normal background radiation caused component of infant mortality rates should vary from about 10/1,000 in such states as Loufsiana and Texas, where the background 1evels are about 75 milliroentgens per year, to about $25 / 1,000$ in such states as Wyoming and Coíorado where background levels exceed 200 milliroentgens per year ${ }^{(59)}$. Wo such correlation of infant mortality with background is apparent. In the years 1960-64, Inclusive, data published by the National Center ior Health Statistics "T0) Indicated that for Texas and Louisiane the mortality rates were 27.1 and 31.0 per 1,000, whereas In Wyoming and Colorado they were 28.5 and 25.3 .

Although natural background makes for the largest ascertainable variations in general population exposures, there are other egstenstic differences. For exanle, weapons testing related doses to persons in "dry" areas of the United States were estinated by the Federal Radiation Council ${ }^{(61)}$ to be about one-third to one-half those for people in "wet" arens, or for 1962 alone alfference in whole body dose of about 10 miliiren between these areas. It does not appear that Sternglase has deconstrated an unequivocal correlation of infant wortality with it.

seldon does sternglase quantitatively conoidor actual dose recelved by 
TABLE V

Infant Mortality Rates/1000 for Counties

Near Humboldt Bay, California*

Year Nine Counties
** $\begin{gathered}\text { Humboldt } \\ \text { County }\end{gathered} \quad \begin{gathered}\text { California } \\ \text { (White) }\end{gathered}$

Hine Countles

California White

$\begin{array}{llllr}1958 & 23.4 & 20.5 & 23.3 & 1.00 \\ 1959 & 26.2 & 26.0 & 22.8 & 1.19 \\ 1960 & 26.7 \pm 3.2 & 25.6 \pm 6.2 & 22.5 \pm 0.52 & 1.19 \\ 1961 & 25.4 & 29.9 & 22.5 & 1.13 \\ 1962 & 26.4 & 28.0 & 21.9 & 1.20 \\ 1963 & 22.3 & 24.6 & 21.5 & 1.04 \\ 1964 & 23.3 & 18.4 & 20.8 & 1.12 \\ 1965 & 21.6 & 26.8 & 21.2 & 1.02 \\ 1966 & 20.8 & 17.9 & 20.0 & 1.04 \\ 1967 & 17.1 & 18.0 & 18.8 & 0.91 \\ 1968 & 17.6 & 17.9 & 18.5 & 17.6\end{array}$

* Used data for 1958-1967 from U.S. Vital Statistics

for 1968-1969 from California Dept. of Public Health, Courtesy of Mrs. M. V. Ruffin

**Deaths were almost al1 white children, e.g. In 1968142 out of 143 infant deaths were white children. 
the population under consideration in his nuclear facility studies. In the one instance of Dresden, for which he cited nearby dose rates, according to Davis and Kahn ${ }^{(47)}$ the rates were misrepresented as being 50 times greater than those given in the original source of the information. They also pointed out several other Inconsistencies in Sternglass' use of their data. Nowhere has Sternglass taken into account the average dose to the involved populations. Some calculated average gaseous effluent related doses to the population within 50 miles of number of the facilities implicated for certain years by Sternglass are shown In Table VI, along with his indicated excess mortality or risk thereof.

If the effects Sternglass concerns himself with cannot be antifactorily demonstrated at dose differences of 10-100 millirem per year, it is indeed difficult to understand how they can be diacerned in connection with average population doses from nuclear facility effluents ranging from one to several orders of magnitude lower.

Even if one accepts Sternglass' postulated dose-effect relationship, al though it 18 about 100 times larger than that derivable from data published by the ICRP $(64,65)$, the almost infinttesmal nature of the average population doses, as shown in Table VI, appear insufficient to produce the clained excess infant mortality. Using a dose-effect relationship of 10 cases per $10^{6}$ man-roentgens, Buck $(66)$ has estimated that an accrued exposure of $3 \times 10^{7} \mathrm{man}-\mathrm{rem}$ would be required to observe radiation-induced 1eukenia. Bven at a much larger dose-effect relationship, the accrued population dosas shown in Table VI do not approach those at which obsarvable additional infant mortality would be anticipaied, above its base-1ine incidence (which is almost 1,000 times that for leukenia).

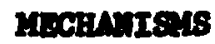

An uneatinfactory aspect of the entire corpue of sternglase' allegations of excess infant wortality from low-1evel radiation is his Inability to adduce 
Indicated Excess Risk or Mortality and Calculated Effluent Doses to Populations in the Vicinity of Selected fuclenr Facilities

Recility

Big Rock

Brookhaven

Dreaden

Humboldt

Indian Point:

Westchester-Rockland

Hew York City

Peach Bottom

West Valley

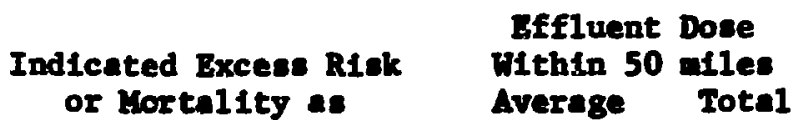

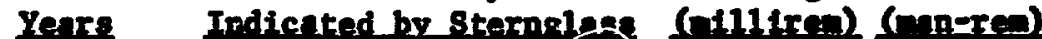

Ref.e

62

$\begin{array}{ccccc}1966-67 & +44.5 \%(\sim 9) & 0.1 & 6^{*} & 62 \\ 1954-60 & \text { Unopecified Dpward Irend } & \sim 0.1 & \sim 125^{\star *} & 43 \\ 1959-68 & 2,500 & 0.025 & 140^{\star *} & 62 \\ 1964-65 & -\quad+4.5 \% & 1.1 & 69^{\star} & 62\end{array}$

1966

$+41 \%(\sim 100)$

$+26 \%(750)$

$<0.002$

$\sim 0.00001$

$0.1^{*}$

62

62

Post 1967 Unspecifled Upward Irend $<0.001 \quad 3^{*}$

62

$1966-67$

$\sim 200$

$<0.1$

63

* Calculated for the year during which excen mortality indicated.

* Calculated yearly average during period in which excess mortality is indicated. 
a satisfactory radiation-induced mechanien and his neglect of other possible causes. A principal mechaniss which he has suggested $(1,6,8,9)$ is the circulation in the body and uptake by the genetic organs and other sensitive glands of short-1ived $90_{\mathrm{Y}}$, which presumably emanates from ${ }^{90} \mathrm{Sr}$ contained in the bones. As has been indicated earlier, Luning has disavowed the pertinence of his experimental Imvestigations to this Sternglass hypothesis. Other Investigators $(67,68)$ have been unable to find any Indication of a transfer of ${ }^{90} \mathrm{Y}$ from bone to soft tissue. At the $48 L \mathrm{~s}$ bearinge on the Shoreham Nuclear Power Station, Goldanan ${ }^{(69)}$ ande a review of the known otudies of radioactive atrontium in aninals and its relevance to an, in none of which was there any Indication of any "extra" genetic or infant mortality effecta.

In several of h1s nuclear effluent related presentationd $(6-7,8-9,11)$, Sternglase repeated earlier suggentions that radiation acte on the glands In such a way as to lead to a greater frequancy of Imaturity at birth, in turn leading to an increased suscaptibility to tainections and to the diseaces of early childhood. A medical authority contacted by Grahen and Trro (30) Indicated that there has been no such incrases in imaturity. Sven if it had occurred, it would not be at all certain that radiation would be unequivocelly iplicated. For example, in a recent study Rosemeske (70) found an inverse correlation between soc10-economic status (an Inferred from educational level) and the proportion of birthe of low weight.

All the foregoing opeculations as to mehanien ifply the intake by the mother, and in some crees the trangfer to the foetus, of redionctivity conteined in the efflueate of the auclear facilities in the vicinity of which excess infent mortality is cletued. There is a considerable body of evidence to suggest otherwies $(43,71-73)$, and that such intakes have been too eanll to be quantifiable, oven in the inodiate vicinity of power 
reactors. They therefore appear to have constituted a negligible exposure pathway to any large number of persone further removed.

In assessing the probability that observable radiation-induced infant mortality might be produced by the nuclear facility effluent radiation levels, other causes which might also constitute a signal to nolse problem must be considered. A significant correlation between socio-econonic status and Infant mortality has been referrad to by Tamplin(35) in his coments on the Sternglass fallout presentation. An epidemological study, conducted within New Fork City by Erhardt, et al ${ }^{(74)}$ in 1966-67, disclosed a range of Infant nortality rates from $41,5 / 1,000$ 1ive birthe in Central Barlen to 13.0 in Maspeth-Forest Bi11s. The authors coment that 10 birth weight Introduces a opecial hazard for Infants, and that there are 1arger proportIons of very tiny babies among non-white infants. They also suggest that women who have no prenatal care produce infants with an extreasy high riak of dying. In addition, they Indicate that repented childbearing at young ages involves an augmented riok of lose of the infant. Another relevant factor, etrese of medical facllities, is euggested by the corralation which Bateman (75) has made between the ouccessively yeariy changes in births and the trend of infant mortality rates in Suffolk County, which is shown In P1gure 10.

From this it appears that a far wore cophisticated aralyols then a atuple tive series correlation of effluent releases with infant wortality is necesaury in order to dewonstrate a reasonable basis for bellef that a cause-effect relationship is operative.

\section{CONGLUSIOAS}

The authors conclude that the prinary data on which sternglaes has built nost of his correlations of melenr facllity effluents and Infant wortality are Inatances of statiotical fluctuations. A wore extensive analyais of many 
years of data, rather than selected years, show mortality changes which fluctuate to give contrary results as well as positive. The latter is exactly what one expects from the small doses and amall populations involved. On balance, there simply 18 no consistent evidence to oupport his call for the $\triangle B C$ to tighten current radiation exposure 1imits.

Furtherwore, the data do not substantiate Sternglese' plen for a shutdown of or a moratorium on nuclear faclifties. Whatever the causes of the Infant mortality, when examined in the light of reported dose-effect relationships, nuclear facility effluents cannot on the basis of the evidence adduced be held to account for any of the total observed infant nortality.

Finally, when effluent release and dose data are considered in the context of eatabliched dose-effect relationships, it appears that even the most maseive inginable nuclear facility oriented epidemological atudies would be unlikely to lead to conclunive knowledge of low-level radiation effects. Curtis (76) has estinated that at an in utero exposure of three millirads, at least $2 \times 10^{8}$. children would have to be followed for ten rare to obtain positive inforation about abnoral mortality.

Although Infant nortality in the Dnited states has decreaced over the past several decades, as hes been indicated by shintin (77), the position of the United State in this rogard, relative to other advanced nations, has worsened over the eame pariod. The causes for this, and eapecially for the excese Infant wortality among lower secio-econonic groups and non-white over the wore privileged in our soefety, call for elucidation by a careful epidenological study, wo that we can act responeibly to allovinte then. 
FIg. 1 U. S. Infant wortality and external background radiation levels, Including fallout increments, at Brookhaven Hational Lemboratory (1935-1969).

Fig. 2

Infant mortality near Dreaden 1966/64, 1966/63 and 1966/60.

FIg. 3

Infant death rates per 1,000 live births, for Grundy and adjacent counties, for control counties, and for Illinois whites; ratio of adjacent to control county death rates and of adfacent to I11inols white denth rates, and Dresden I gaseous emiseions (k(1/yx), 1954-68.

Fig. 4 Infant death rates per 1,000 1ive births, for ten counties nearest the Big Rock Point Reactor and for Mflchigan whites; ratio of ten neareat counties to Hichigan white death rates, and Big Rock gaseous enisetons (kCi/yr), $1955-68$.

F1g. 5 Infant deati rates in California near lluboldt $(1964=100)$, and Humboldt reactor gascous entsatons (1963-67).

Fig. 6 Infant death rates per 1,000 11ve birth for Buboldt County, for nize adjacent counties, and for California whites; ratio of adfacent county to Californis white death rates, and Buboldt Renctor gaceous eniscions.

Fig. 7 Ratio of Infant wortality rates for Hestchester and Rockland counties to infant nortality rates for Haseru county, Indian Point I gaseous calestons (1954-69).

F18. 8 Changes in Infant wortality rates vo. distance from Indian Point I, 1966-1961 and 1968-196? .

$$
1961 \quad 1962
$$

F18. 9 Infant mortality rates for Suffolk County, Naseau County and New York state (except new Iork City), 1949-69; Brookhaven 1iquid effluant ectivity ( $\mathrm{Cl} / \mathrm{yx}$ ), and average expoure from Bil effluent $41 \mathrm{Ax}$, and external background at Bit perieter (ailitrocetgens/yx), 1949-69.

818. 10 Relation of atrain on fecilities to fetal death rate for Suffolk County, 1950-1970. 


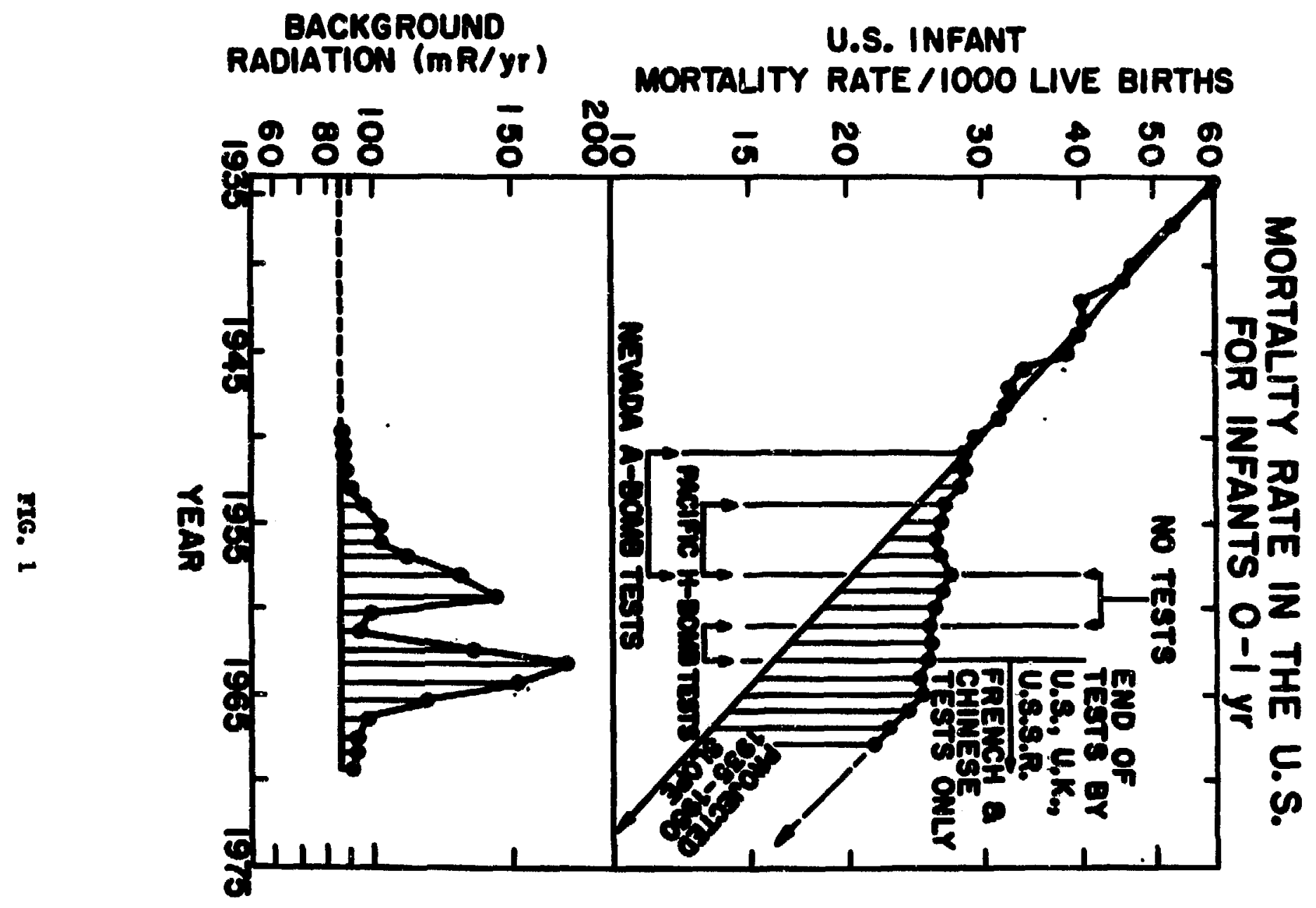




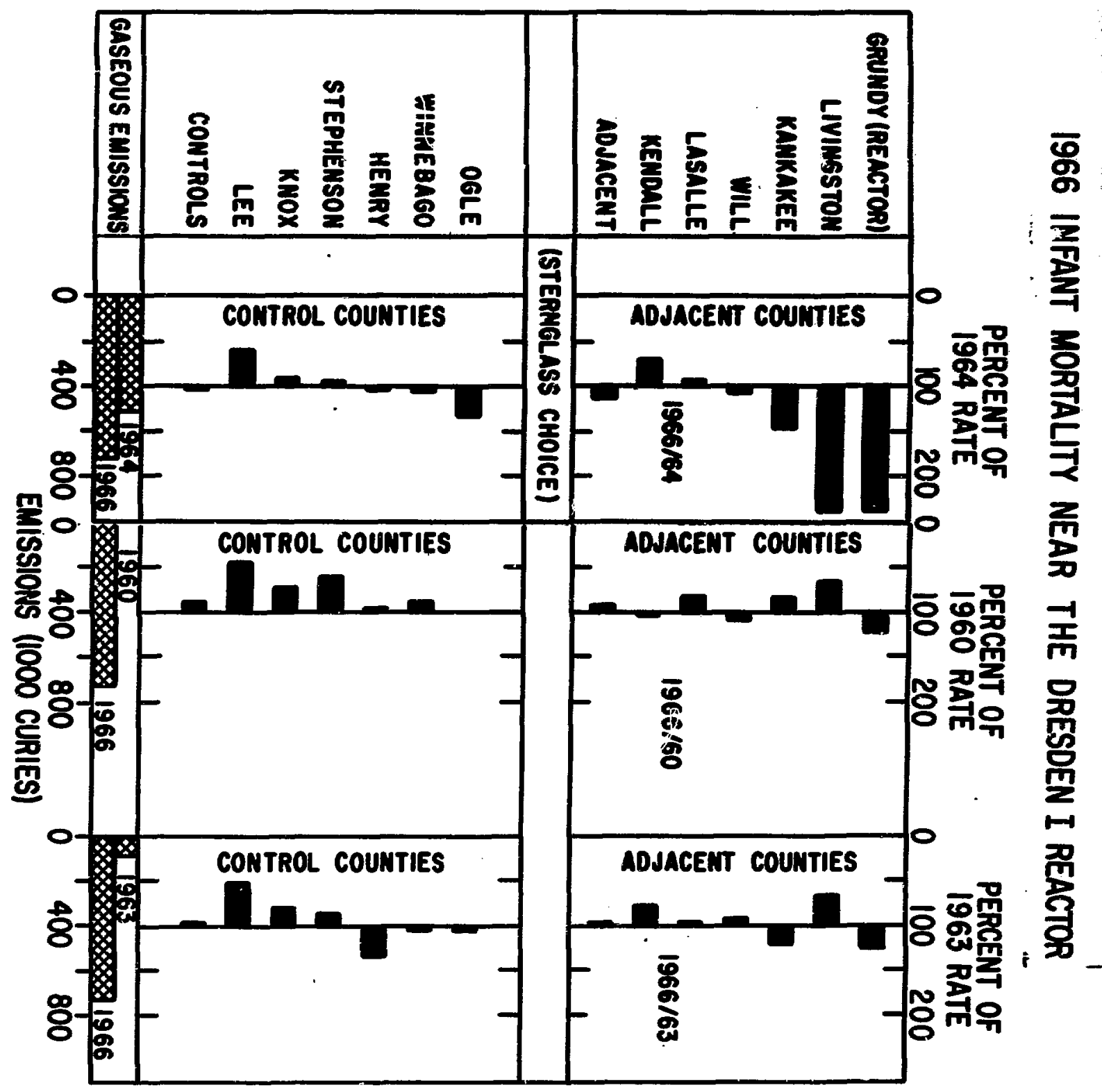




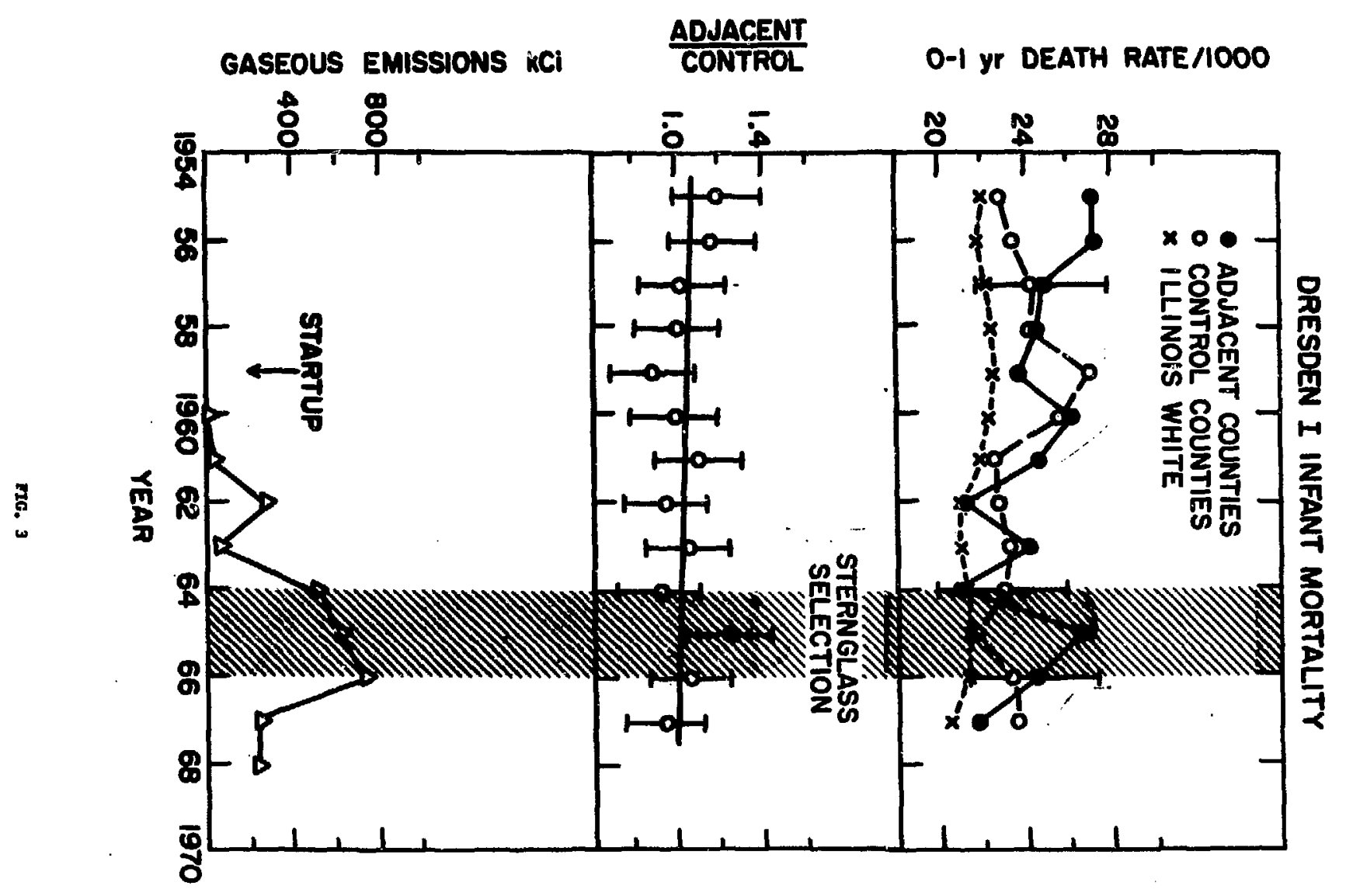




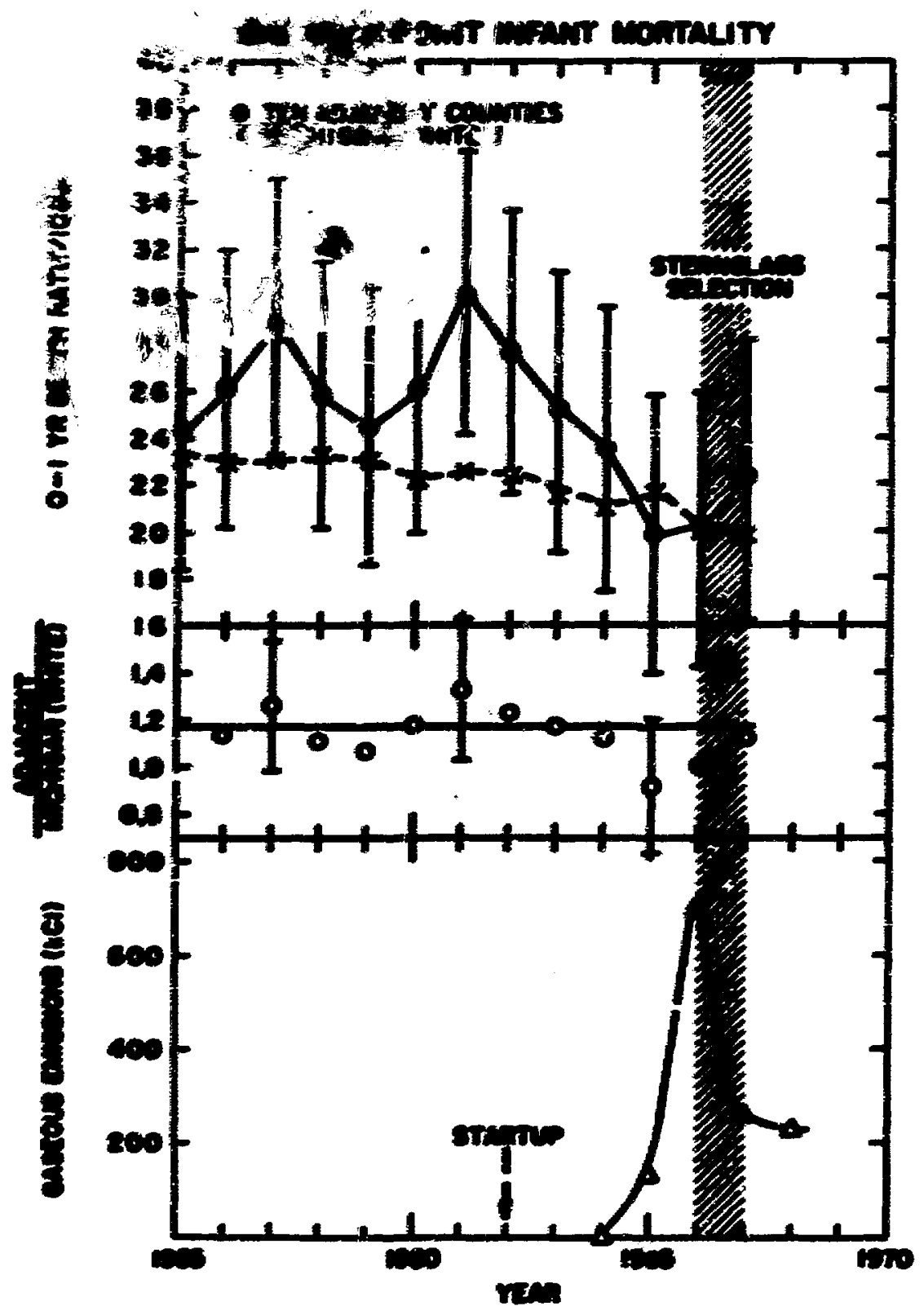

no. 


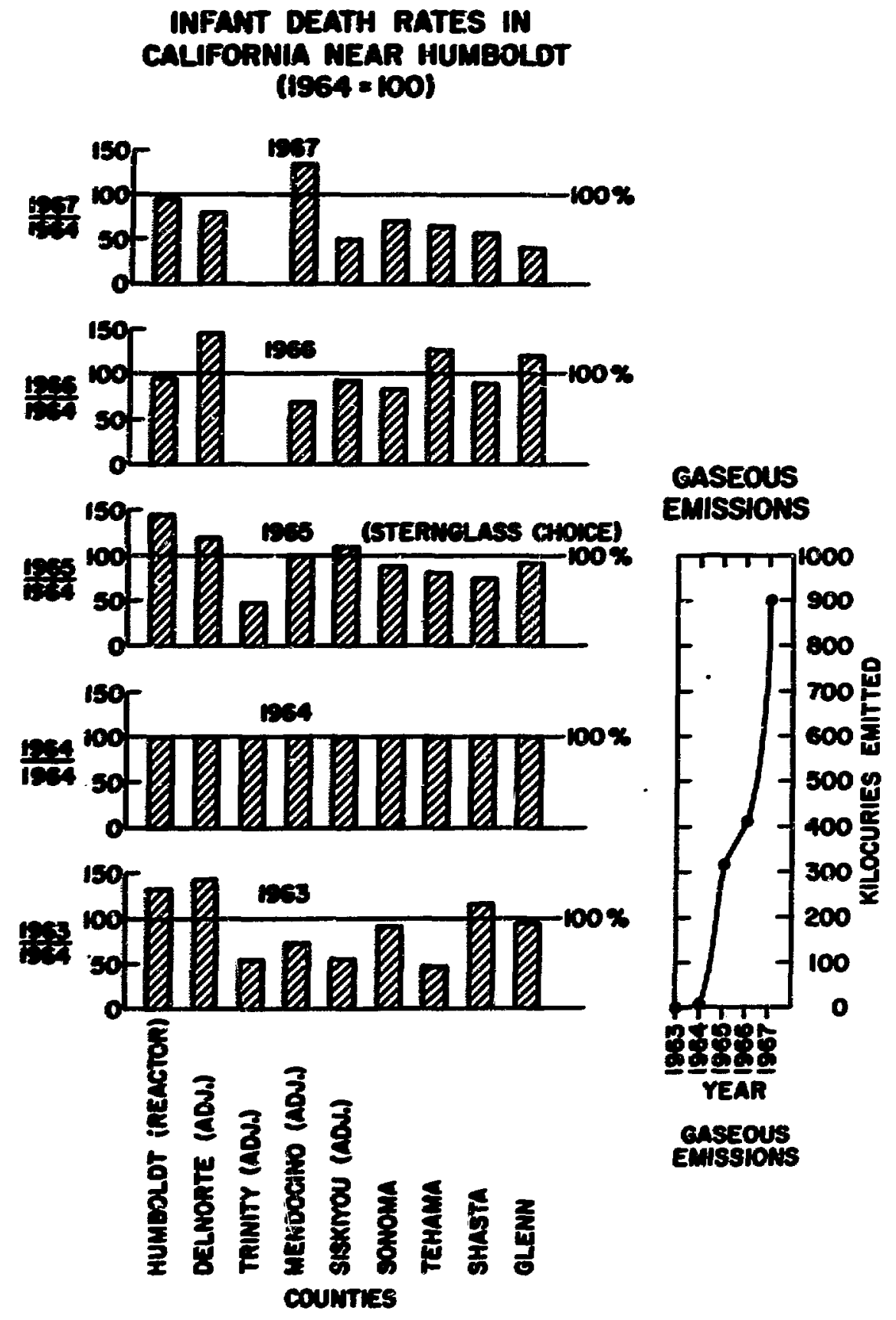

IIG. 5 


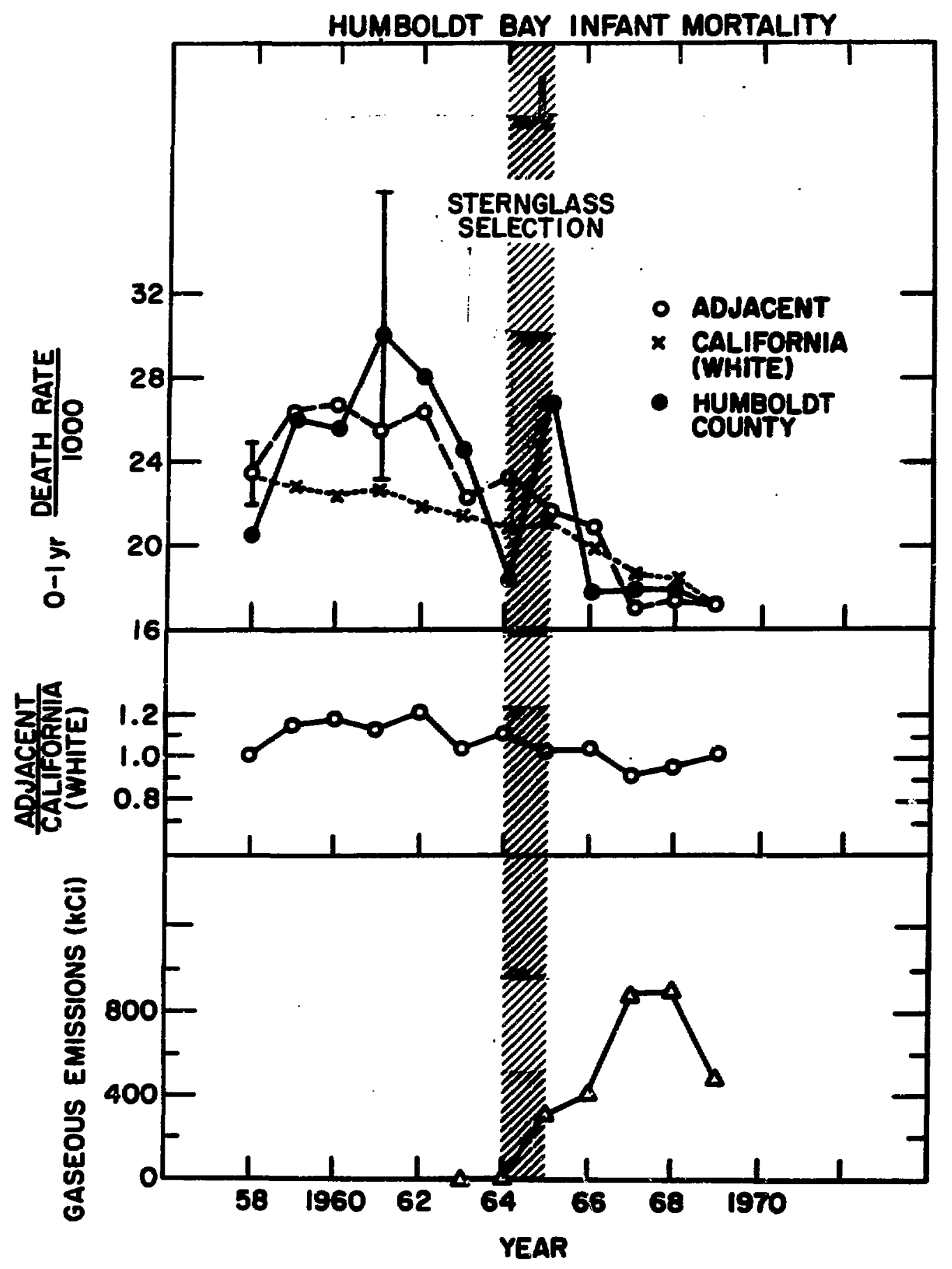

FG. 6 

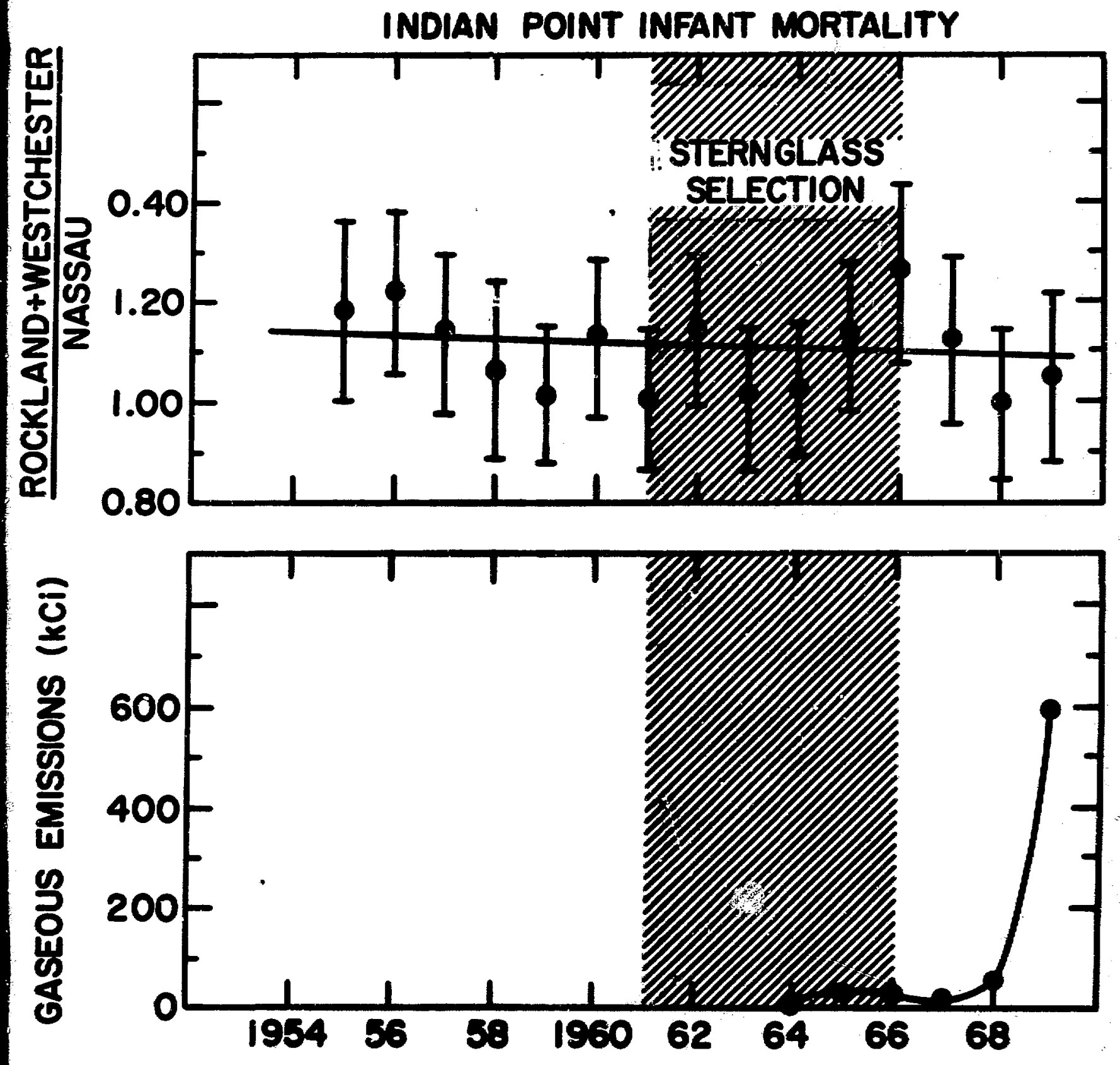

120. 7 


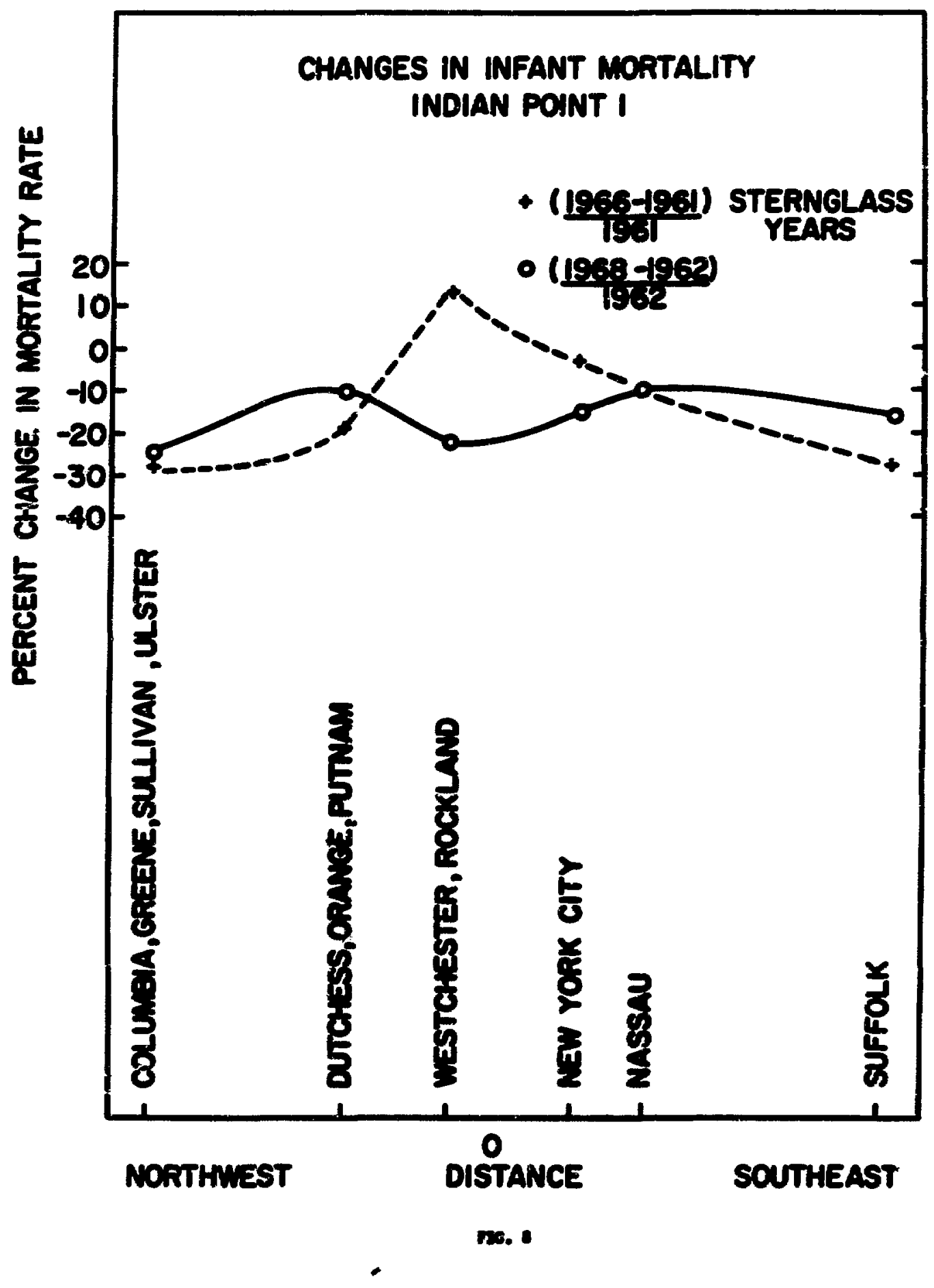


A COMPARISON OF INFANT MORTALITY IN SUFFOLK COUNTY, NASSAU COUNTY AND NEW YORK STATE WITH EXTERNAL RADIATION LEVELS AND EFFLUENT RELEASE AT BROOKHAVEN NATIONAL LABORATORY

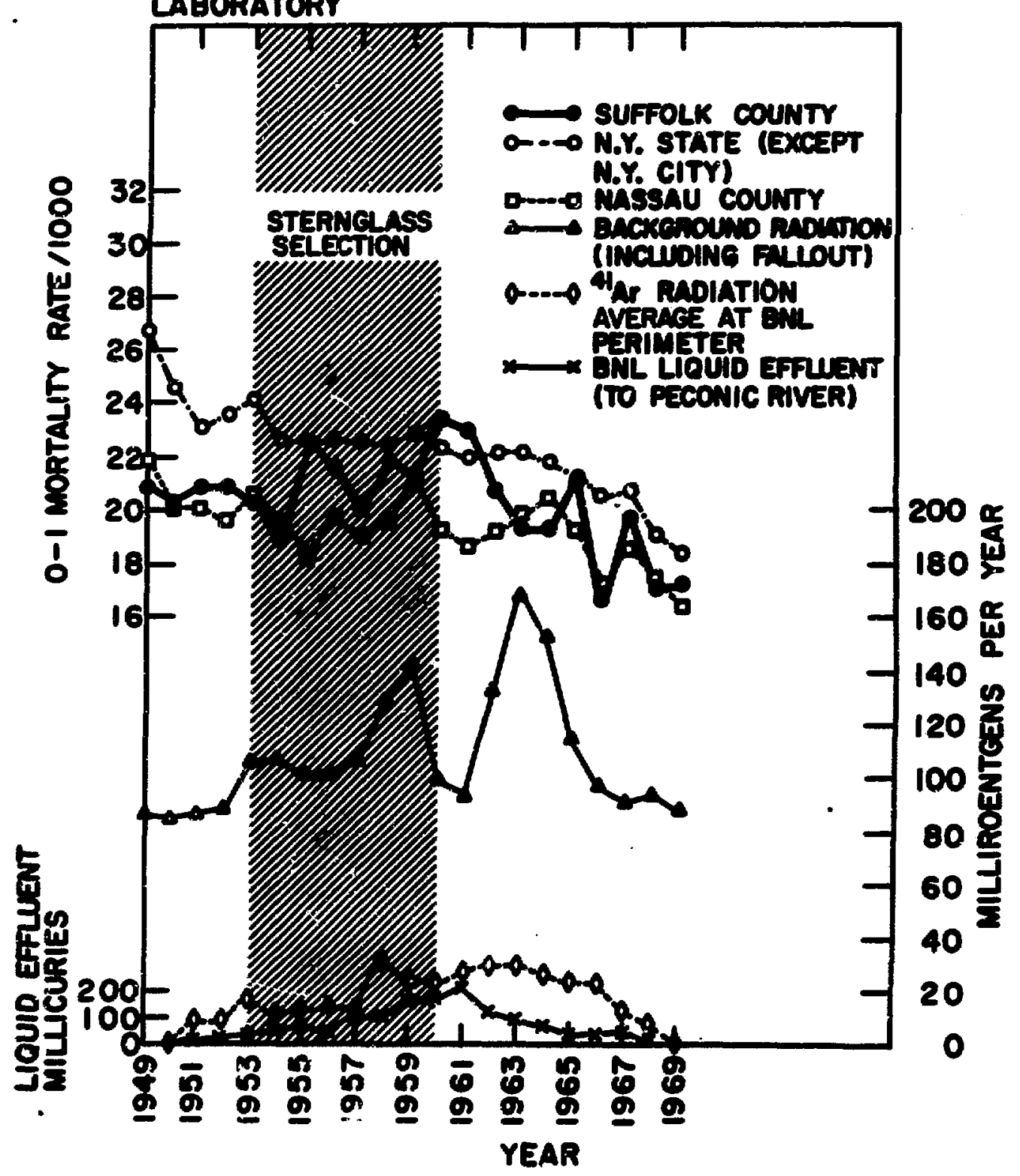

rre. 


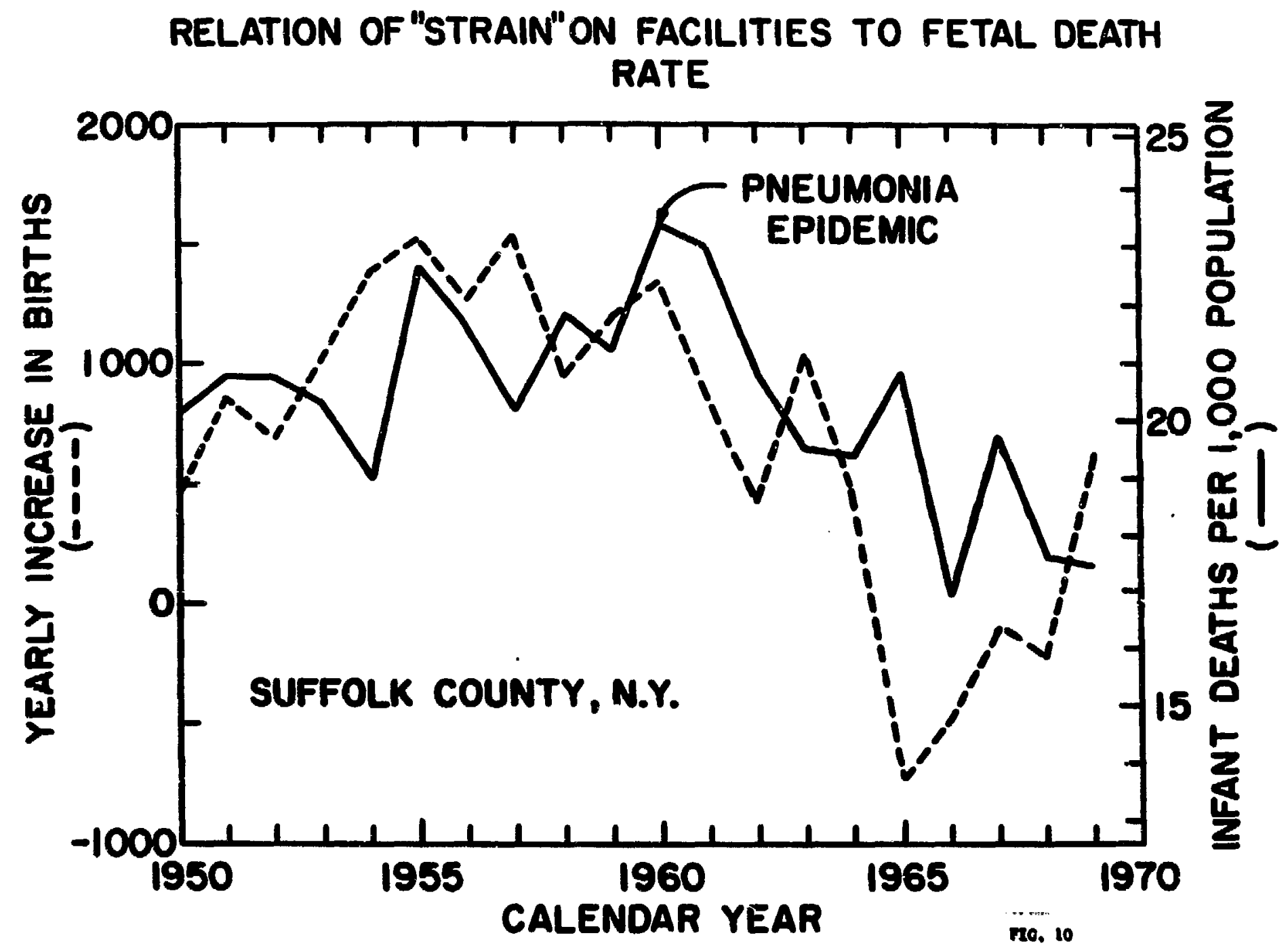




\section{REHIMGS}

1. B. J. Sternglase, "Iow-Level Radiation Effects fron meloar Fisalon

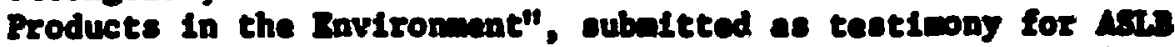
Hearias on shorehan Euclear Bower gtation 10. 1, Docket 50-322, $5 / 3 / 70$.

2. B. J. Sternglese, "Infant Hortelity and licelear Power Generation",

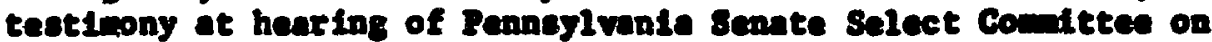
Reactor 8itins, Barribburs, 10/21/70.

3. E. J. Sternglese, "Infant Fortality Ghenges Iear a Huclear Fuel Reprocesolns Plavt", y. of Pch., 11/30/70.

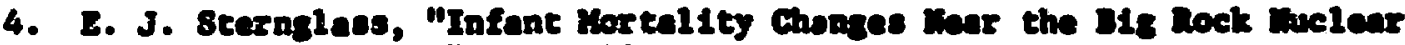
Bowar station", Jan. 1971.

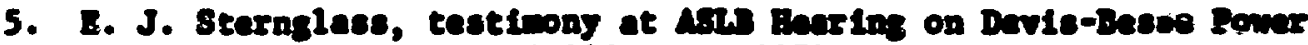
Reactor, Docket 50-346, Jam. 1971.

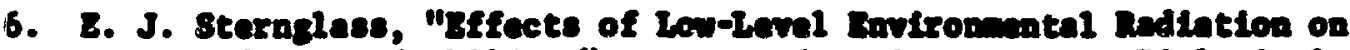
Infants and Childrea", presented at 8yposivin on Blolostenl consequances of Inviromentel Indiation, 8. of W'ra. I11., 3/20/71.

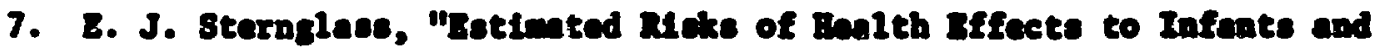

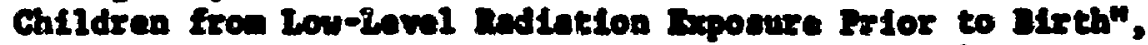

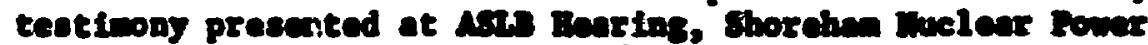
8tetion 10. 1, Doeket 50-322, 4/20/71.

8. B. J. 8tornglase, "Low-Level hadintiea Bffeete on Infonte and Childrea

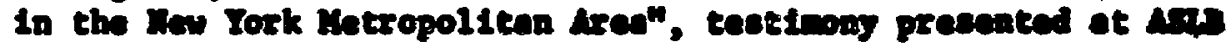

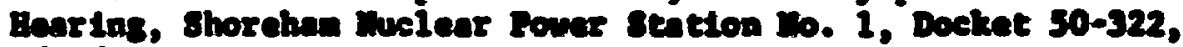
$4 / 20 / 71$.

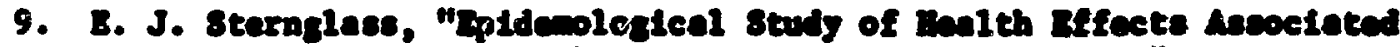
wth Iediation Diccharged from buelere Fectlitied", presented

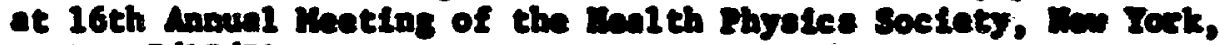
11. 8., 7/15/71.

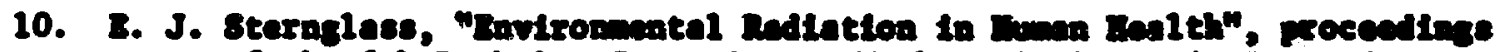

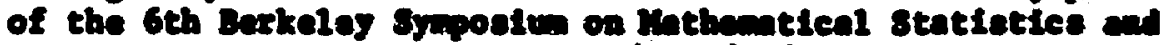
Brobablitey, Dexkeles, Cal1f., 7/19-7/22/71, to bo pobltabd by the 0. of Cal. Irese (J. Iosman, ad).

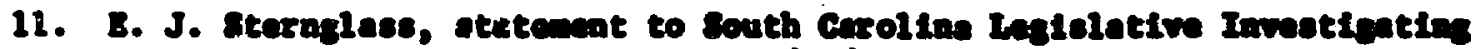
Comittee, colubie, 8. C., g/30/7.

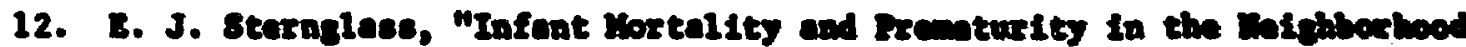

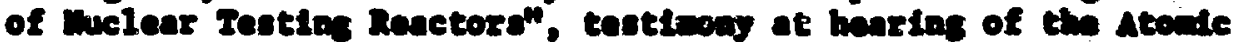

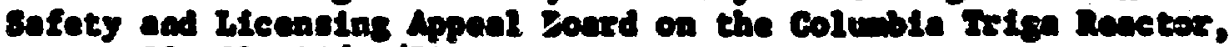
Docket 50-200; 10/22/71.

13. ....., "standarde for Frotection Aghinot nediatton", Itt1e 10, Fart 20, u.8. Code of Fodaril Reculations.

14. ...... Mecomendatione of the Interantenal comicolon on Rellologiend

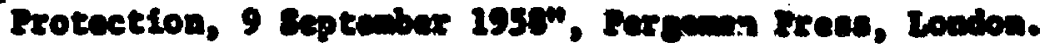


15. ....., "Eabic Radiation Protection Griterie", nep leport Io. 39 (1971).

16. ....., "Iroposed Humrical Guldace to Reep Rediocetivtey in LightHater-Cooled Buelear Raseter Bffluente as Iov as Irecticable", anodinate to Title 10, Rert 50, 0.S. Code of Pederel Iegulations, 6/9/71.

17. R. Gillette, Mediation Fissions, Anc Gufdelines Hove Tonard Gritice Pooltion", Setmat, 172, Pp. 1215-16, (1971).

18. H. Bope and J. Joung, "Ihe Great meIest Dobete: Are Our Iobles' Ifives in Danger", Ralioglt, 1/72.

19. B. J. Stexnglase, "Gancer, Relation to Fronntal Indintion to Developmat of Disase in chtlahood", Satreq, 140, Pp. I102-04 (1963).

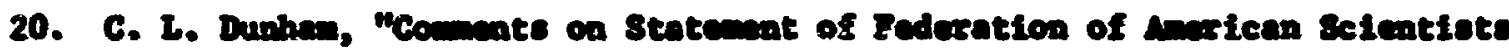

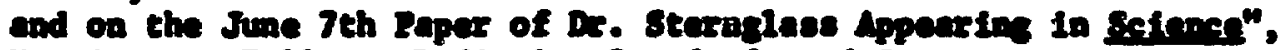

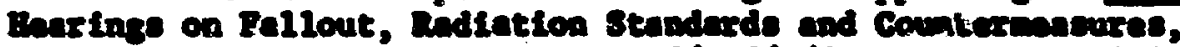

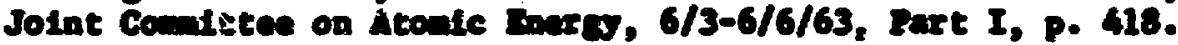

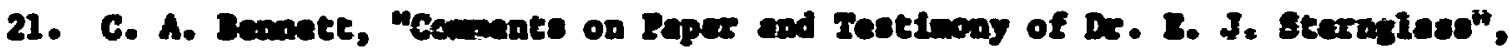
ible, Bart 2, p. 1036.

22. B. Heathod, "gtatemat", Ibid., Rat 2, p. 6010.

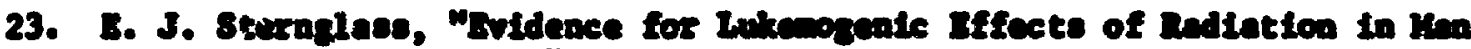
at Iow Doce Rated", presented to the 13th Ammal rmeting of the Balth Ihyalce society, Danver, Coto., 6/20/68.

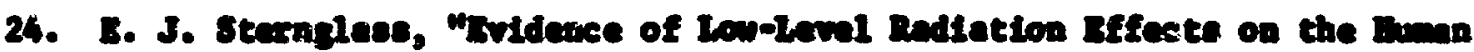

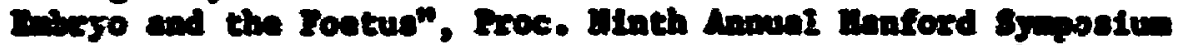

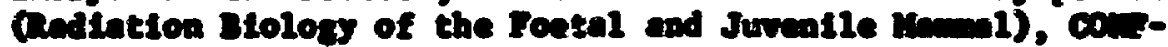
csosol (19s9).

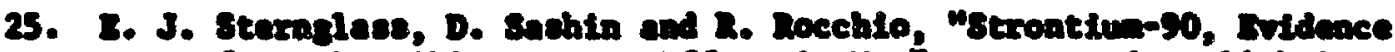

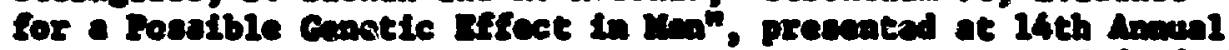

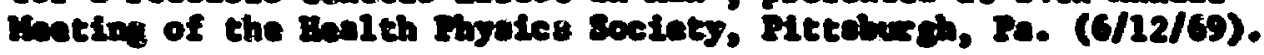

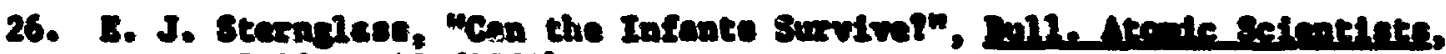
25:10 p. 28 (1969).

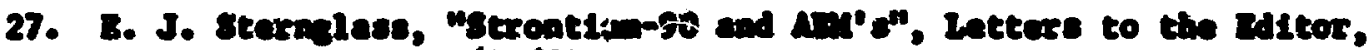
1.7. 71 , G/20/69.

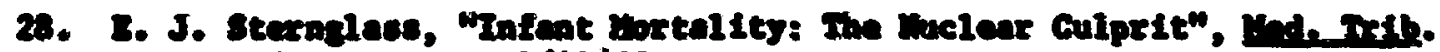

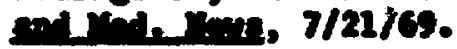

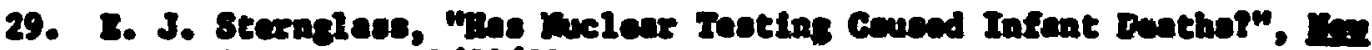
sesentint, 7/24/6s.

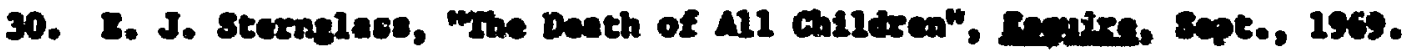

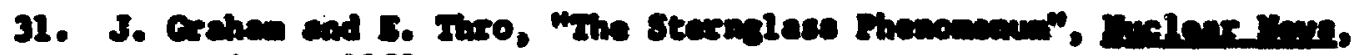
cet., $18 \mathrm{~s}$. 
32. P. H. Doffey, "Brnest J. Starnglasa: Controvaralal Prophet of Doom", Setrnes, 166, pp. 195-200, (1969).

33. A. Stewart: "The Pitfalle of Bxtrapolation", In: Sefentit:, 7/24/69.

34. H. B. Wrenn, "Data on Strontium-90", Letters to the Editor, D.Y. TIm, 9/13/69.

35. L. Sagan, "A Reply to Steragland", Ins setentint, 10/2/69.

36. A. R. Templin, "Ietel and Infant Mortality and the Buvironant", Bn11. Ato.ta sotentint:, 25:10, p. 23 (1969).

37. H. Blecabud, J. Berley, H. B. Bellex, 8. Baxrte and H. B. Hrem, "gtatcant on the Aseartions of K. J. Sternglase", prepared by an ad hoc condttee of the Greater lew York Chapter of the Boalth Fingales society, 10/15/69.

38. P. J. Ifndop and J. Rothblat, "Strontiun-90 and Infant Vortality", Intare, $12 / 24 / 69$.

39. E. Tompleins and H. L. Drow, "Evaluation of a Posalble Cause Relation Dativen Ballout Doposition of 8trontiu-90 and Infant and Fetal Bortailty Irende", Das 69-2, (1969).

40. P. Greanuld and 8. Kiren, Molation of Radlosctive Fallout to Ieukenia and Ietal Hortality: A Reconsideration", T.19 690501.

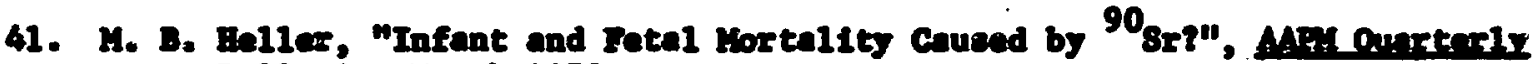
Bnllitin, Hereh 1970.

42. ....., "yiore on Radiosctive Fallout", 8tatcont by Comittee on Environmentel Bnenrde, Anxican leedery of Redintrice, 4/15/70.

43. A. P. Bul1, "A Recapitulation of Effluant Relences and Related Ghapee in Reckpround Radiation Ievis at Brookhaven Intiornl Laboratory, and som Comparicons with Those Ascolated with buclear Power

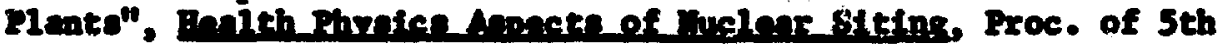

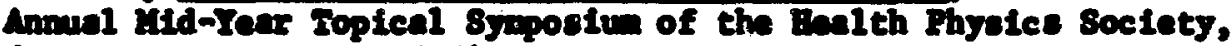
(P. Vollleque, ed., 1970).

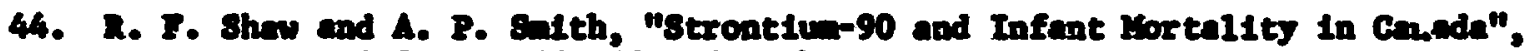
Inture 228, Pp. 667-669, (1970).

45. 1. B. Low, 8. Lotinhardt and H. B. Kaje, "Low Level Iadiation and J. S. Yortelity", Ereduate school of Induatrial Adainistration, CarnefleHellon Uatv., Working Paper 19-70-1.

46. ....., "Vital Statiotice of the Dnited 8tated", Vo1. 1, pp. 1-20 (1959).

47. A. R. Dovte and Iexmord Rmh, "A Gitical Review of 'Infant Kortality and muelear Rownx Ceneration' by J. J. 8terngleag". Teetiony at 8tate of IIIInois Pollution Control Deard, Horr Le, I11, , 12/11/70. 
49. ....., "A Rationale of Dr. Sternglase' Paper, 'Infant Mortality Changes Near the Big lock Point liclear Power Station. Charlevolx, Mich."", Michigan Depurtment of Public Health, 2/19/71.

49. T. H. Gerusky, "Revised Statement Concerning Dr. Sterngless' Allegations Regarding Infant and Nuclear Power in Pennsylvania", Office of Rad. Health, Penn. Dept. of Bnv. Resources, April, 1971.

50. A. P. Hu11, "Comments on Submission by Dr. Brnest Sternglase", testimony presented at AStB Hearing, Ghoreham Huclear Power Station Bo. 1, Docket 50-322, 5/7/71.

51. L. A. Sagan, "Cosments on Supplenental Testimory of Ernest Sternglase at the Shoreham Bearing", teatimony presented at ASLB Hearing, Shoreham Nuclear Power Station No. 1, Docket 50-322, 5/10/71.

52. E. A. Toupkins, "Infant Hortality Arouxd Three Nuclear Reactors", presented at 6th Berkeley Symposium on Kathematical Statistics and Probability, U. of Calif., 7/19-7/22/71, to be published by the U. of Cal. Press (J. Neyman, ed).

53. ....., "Selected Health Statistics 1960-69, for Counties in New York State Having Nuclear Facilities", Hew York State Dept. of Health, $6 / 30 / 70$.

54. A. Gendon, Statement following presentetion by B. Sternglass at 16th Annual Meeting of the Health Physics Society (see Ref. 9), 7/15/71.

55. D. Moel ler, Statenent to S. Carolina Legislative Committee Investigating Allied-Gulf Fuel Reprocessing Plant, also reported in Info, No. il (Oct. 1971).

56. W. W1tzig, Affidavit submitted to the Atomic Safety and Iicensing Apperl Board, with reference to the Columbia Triga Reactor, Docket 50-208, $11 / 16 / 71$.

57. A. M. Stewart, personal cownunication, 5/6/71.

58. H. H. DeGroot, "Statistical Studies of the Effect of Low-Level Radiation from liclear Reactors on Buman Health", proceedings of the 6th Berkeley Symosium on Mathematical Statistics and Probability, Berkeley, Calif., 7/19-7/22/71, to be published by the U. of Cal. Press (J. Heyman, ed).

59. R. Minx, B. Shleien, A. พ. Klement and C. R. Miller, "Estimates of Ionizing Radiation Doses in the United States 1960-2000", EPA Draft, June 1971.

60. ....., "Infant Mortality Trends, United States and Each State 1930-64", National Center for Health Stutietics, Series 20, No. 1 (1965).

61. ....., "Bstimates and Evaluation of Fallout in' the United States from Huclear Weapone Testing Conducted Through 1962", IRC Report 10. 4 (1963). 
62. C. G. Gamertsfelder, "Regulatory Experience and Projections for Design Criteria", Sou. Conf. Environ. Rad. Protection at Nuclear Power Plants, St. Petersburg, Fla., 4/22/71.

63. B. Shleien, "An Estimate of Radiation Doses Received by Individuals Living in the Vicinity of a Nuclear Fuel Processing Plant in 1968", BPH-NEHPL 70-1, (1970).

64. ....., "The Evaluation of Risks from Radiation", a report prepared for Committee I of the ICRP, Health Physics, 12:2, pp. 239-302 (1966).

65. ....., "Radiosensitivity and Spatial Distribution Dose", ICRP Publication 14, Pergamon Press (1969).

66. C. Buck, "Population Size Required for Investigating Threshold Dose in Radiation Induced Leukemia", Science 129, Pp. 357-58 (1959).

67. R. H. Mole and A. H. Ward, "Yttrium-90 in Gonads of Monkeys Containing Strontium-90", Nature, 226, p. 175, (1970).

68. W. J. Clarke, R. F. Palmer, E. B. Howard and Patricia L. Hackett, "Strontium-90: Effects of Clixonic Ingestion on Farrowing Performance of Miniature Swine", Science, 169, pp. 598-600, (1970).

69. M. Goldman, "Studies of Radioactive Strontium in Animals and its Relevance to Man", AEC Staff submitted testimony at ASHB Hearing, Shoreham Nuclear Power Station No. 1, Docket 50-322, 5/3/71.

70. I. Rosenwaske, "The Influence of Socio-economic Status on Incidence of Low-Bir th Weight", RHsYA Health Reports, 86:7, pp. 641-9, (1971).

71. B. Kahn, et al., "Radiological Surveillance Studies of a Boiling Vater Nuclear Power Reactor", BRA/DER 70-1 (1970).

72. J. W. Lentsch, et al., "Manmade Nuclides in the Hudson River Bstury", Health Phrsics Aspects of huclear Siting, Proc. of 5th Annual Mid-Year Topical Symposium of the Bealth Physics Societs, (P. Voilleque, ed., 1970).

73. R. Blanchard, et al., "Radiological Surveillance Studies of a Fin muclear Power Station - Estimated Dose Rates", presented at the 17th Annual Heeting of the Health Physics Society, Rev York, 7/15/71.

74. C. J. Bxhardt, H. Abrahanson, J. Parker and F. Melcon, "An Bpidemologieal Approach to Infant Hortality", Axch, Mrv, Benlth, Dol. 20, pp. 743-757, (1970).

75. J. I. Bateman, Information prepared for Suffolk Selentisto for Clemer Power and Safer Environment, 5/17/71.

76. H. J. Curtis, "Coments on Subniesion by Dr. Ernest Sternglass", AST

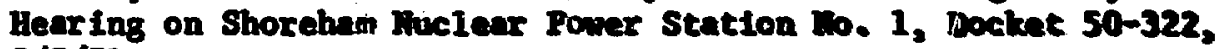
5/7/72.

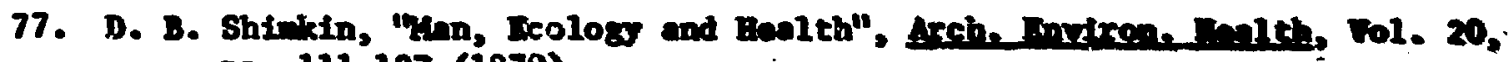
pp. 111-127 (1970). 